\title{
Geochemical characterization of an urban lake in the centre of Rome (Lake Bullicante, Italy)
}

\author{
Monia Procesi (1), Daniele Cinti (1), Barbara Casentini (2), Jacopo Cabassi (3), Stefano Amalfitano (2), \\ Luca Pizzino (1), Francesco Capecchiacci (4), Andrea Butturini (5) \& Stefano Fazi (2)
}

\section{ABSTRACT}

Urban lakes have become increasingly important in the planning of urban ecology, green infrastructure and green areas in European cities. This paper describes the chemical, isotope and microbial features of Lake Bullicante, a small artificial lake located within the urban area of the city of Rome. It has an anthropogenic origin due to excavation works that intercepted the underlying aquifer, giving rise to a water body. The lake area is $7.000 \mathrm{~m}^{2}$, with a maximum depth of $7 \mathrm{~m}$ and located on the distal deposits of the Alban Hills Volcanic District in an area named "Acqua Bullicante" (i.e. Bubbling Water), where degassing phenomena were historically recorded. The proximity of this volcanic district motivated the study on Lake Bullicante as a potential open-air laboratory to trace possible degassing phenomena in a highly urbanized area. A preliminary geochemical and microbial sampling survey was carried out in winter 2018. Samples were collected along a vertical profile of the lake from the surface to the maximum depth. Major, minor, trace elements, dissolved gases and stable isotopes $\left(\delta \mathrm{D}-\mathrm{H}_{2} \mathrm{O} \delta^{18} \mathrm{O}-\right.$ $\mathrm{H}_{2} \mathrm{O}, \delta^{13} \mathrm{C}-\mathrm{CO}_{2}$ ) were analyzed, along with the analysis of ${ }^{27} \mathrm{Sr} /{ }^{86} \mathrm{Sr}$ ratio. The microbial community characteristics were analysed by epifluorescence microscopy (CARD-FISH) and flow cytometry. The chemical composition and water isotopes suggest that lake water has a meteoric origin and is related to a $\mathrm{Ca}-\mathrm{HCO}_{3}$ shallow aquifer hosted in volcanic rocks. This is confirmed by both the ${ }^{87} \mathrm{Sr} /{ }^{86} \mathrm{Sr}$ ratio of lake water, which falls in the range of values of Alban Hills volcanites, and the chemical-isotopic composition of neighboring wells. A relatively high concentration of dissolved $\mathrm{CO}_{2}$, its isotopic signature $\left(\delta^{13} \mathrm{C}-\mathrm{CO}_{2} 20 \%\right.$ V-PDB $)$, and the high content in organic matter (DOC $10-30 \mathrm{mg} / \mathrm{L}$ ) suggest for the lake an eutrophication state with denitrification also occurring. Considering the relatively high concentrations of dissolved $\mathrm{CO}_{2}$, an external input of carbon dioxide cannot be completely excluded and as a consequence, not even the hypothesis of mixing processes between biotic and inorganic $\mathrm{CO}_{2}$. This makes further investigations necessary especially during the summer, when the lake is stratified. A summer survey could be also useful to better understand the microbial processes into the lake, its eutrophication evolution and health status, and to plan eventual proper remediation strategies, providing important tools to the local administration and stakeholders to improve, protect and preserve this ecological niche.

KEY wORDs: Lake Bullicante, fluid geochemistry, microbiology, Rome, Alban Hill Volcanic District.

(1) Istituto Nazionale di Geofisica e Vulcanologia, Via di Vigna Murata 605, 00143 Roma, Italy.

(2) Water Research Institute, National Research Council, CNR - IRSA. Via Salaria km 29.300 - CP10, 00015 Monterotondo, Roma, Italy.

(3) Institute of Geosciences and Earth Resources, National Research Council, CNR - IGG, Via La Pira 4, 50121 Firenze, Italy.

(4) Dipartimento di Scienze della Terra, Università degli Studi di Firenze, Via La Pira 4, 50121, Firenze, Italy.

(5) Department de Biologia evolutiva, Ecologia y Ciencies ambientals, Universitat de Barcelona, Catalonia, Spain.

Corresponding author e-mail: monia.procesi@ingv.it

\section{INTRODUCTION}

Urban lakes are generally man-made ecosystems resulting from excavation activities, with a surface area of a few hectares and an average depth of 3-5 $\mathrm{m}$ or less (NASELli-Flores, 2008). They are particularly sensitive to water pollution and eutrophication processes owing to excess enrichment of nutrients from inefficient wastewater treatment, agricultural expansion, application of chemical fertilizers and inadequate soil uses (GonZÁlEZ \& RoldÁN, 2019; WAGNER \& ERICKSON, 2017).

Lake Bullicante (Fig. 1) is a typical example of urban lake; it is located in the eastern part of the urban area of Rome (on the left bank of Tiber River) and close to its historical centre. The lake appeared in the 1990s following illegal excavation works, which intercepted the underlying aquifer causing the rise of a small waterbody (about 7,000 $\mathrm{m}^{2}$ ). Due to this event and to the citizen protests, the works were suspended and the whole area expropriated. The site remained closed until 2016, favouring re-naturalization processes, new ecological systems and forbidding additional anthropogenic transformations (BATTISTI et alii, 2017).

The lake is named after the Acqua Bullicante ditch, and it is locally known also as Lake "Ex SNIA", from the nearby textile factory SNIA Viscosa, which was active until the early 1950. The name Acqua Bullicante (i.e. bubbling water) suggests the occurrence of degassing phenomena, connected to the intense and well documented hydrothermal activity which characterizes the nearest volcanic districts of the Alban Hills and the Sabatini Mountains, on whose deposits the city of Rome was built (CHIODINI \& FrondinI, 2001; Pizzino et alii, 2002; Carapezza \& TARChINI, 2007; CinTI et alii, 2017; CARAPEZza et alii, 2019; Minissale et alii, 2019). It is supposed that the Acqua Bullicante ditch was hosted along a fault (CAPELli et alii, 2008). CAMPONESCHI \& Nolasco (1982) claimed that violent $\mathrm{CO}_{2}$-degassing from waters was visible in the surrounding areas. However, due to the intensive uncontrolled building expansion, including the canalization and ditch covering, no trace of degassing phenomenon is visible nowadays.

In this study, we describe the geochemical features of the lake comparing chemical, isotopic and microbial characteristics, along a vertical profile from the lake surface to the bottom $(\sim 7 \mathrm{~m})$. More specifically, we explored whether the target site could represent an openair laboratory to $i$ ) better understand the geochemical features of the groundwater in a highly urbanized area like Rome, ii) trace and investigate on possible degassing 

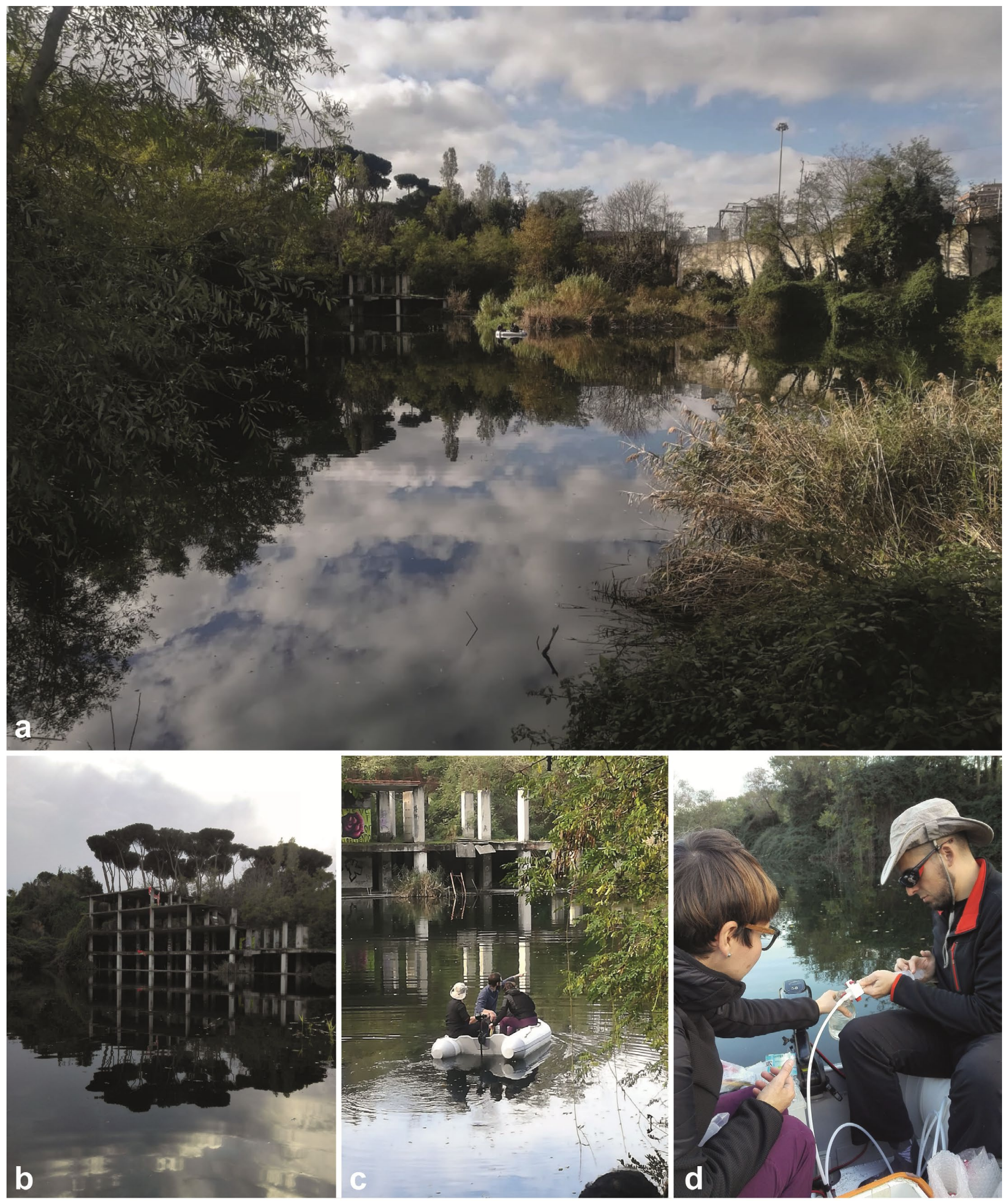

Fig. 1 - a) Panoramic view of the Lake Bullicante. b) Structure of the unlawful shopping centre. c) Researchers on INGV inflatable boat. d) Lake water sampling. (Photo credits: a) Maurizio Pastano). 
phenomena and iii) assess main biogeochemical processes occurring. The results will contribute to proper lake environmental protection strategies, thus providing important ecosystem services to the local administrative entities and stakeholders.

\section{GEOLOGICAL SETTING OF THE STUDY AREA}

The Alban Hills Volcanic District (AHVD) is part of the Roman Comagmatic Province (Washington, 1906), a NWstriking sequence of silica-undersaturated potassic volcanic districts developed in an extensional tectonic regime along the Tyrrhenian Sea margin of central Italy. AHVD was characterised by intense volcanic activity between 600 and $20 \mathrm{ka}$ and, at present, it is considered at a quiescent state (Funiciello et alii, 2003; Freda et alii, 2008; MARra et alii, 2003). The activity of the AHVD has been characterized by three main phases named Tuscolano-Artemisio (600$350 \mathrm{ka})$, Faete (350-270 ka) and Hydromagmatic (260-20 ka), respectively (FunICIELlo et alii, 2003; MARRA et alii, 2003) (Fig. 2a). The volcanic products overlie sedimentary deposits constituted by sandy-silt-clay, related to the PaleoTiber alluvia (Pleistocene), and Pliocene marine clays.

Lake Bullicante is located in the north-eastern distal sector of the AHVD, has an elliptical shape $(130 \mathrm{~m}$ x $80 \mathrm{~m}$, in the largest point), a surface of about $7000 \mathrm{~m}^{2}$, a maximum depth of $7 \mathrm{~m}$ (Fig. 2a-c) and it is hosted on the deposits of the first phase of the volcano activity, in proximity to the Acqua Bullicante paleo-ditch (Fig. 2d).

The whole stratigraphic sequence is displaced by a high angle NNW-SSE fault (CAPELLI et alii, 2008). The axis of the Acqua Bullicante ditch and the hydrographic network were probably controlled by this fault, in correspondence of which important degassing phenomena were observed (CAmponeschi \& Nolasco, 1982).

From a hydrogeological point of view, a shallow aquifer, hosted in the AHVD deposits, was identified in the study area and probably resulting from the merge of several aquifers that are instead well defined on the flanks of the Alban Hills (LA Vigna et alii, 2016). This aquifer is characterized by a piezometric level between $20-25 \mathrm{~m}$ asl and is bounded at the base by a very low-permeability bedrock, formed by a basal clayey-sandy complex acting as aquiclude (LA VIGNA et alii, 2016).

\section{METHODS}

\section{Field MEASUREMENTS}

Temperature $\left({ }^{\circ} \mathrm{C}\right)$, Electrical Conductivity (EC in $\mathrm{mS} /$ $\mathrm{cm}$ at $\left.20^{\circ} \mathrm{C}\right), \mathrm{pH}$ and dissolved $\mathrm{O}_{2}(\mathrm{mg} / \mathrm{L})$ were measured in winter $2018\left(21^{\text {st }}\right.$ Nov) along the lake vertical profile, from the lake surface to the bottom (7 $\mathrm{m}$ depth) and at interval of $1 \mathrm{~m}$, by using dedicated electrodes (for T, $\mathrm{pH}$ and EC) and gas chromatography analysis (for dissolved $\mathrm{O}_{2}$ ). The measurements, along the entire profile, were also repeated in summer (28 ${ }^{\text {th }}$ June 2019$)$ using a multi-parametric probe (Idromarambiente SCRL 1P-188A) equipped with a data logger for data storage. For details on the use of the probe and the sensors precision, refer to CABASsI et alii (2019). Alkalinity (Alk, mg/L) was measured in situ by acidimetric titration (AC) with $0.05 \mathrm{~N} \mathrm{HCl}$ (analytical error <5\%). The water depth (m) was measured by using an echo-sounder GARMIN Stiker Plus 92 SV equipped with a transductor GT52.

\section{WATER AND DISSOLVED GASES SAMPLING AND ANALYSIS}

Water and dissolved gas sampling for both geochemical and microbiological analyses was carried out along lake vertical profile from the surface to the bottom at intervals of $1 \mathrm{~m}$ at a site corresponding to the deepest point of the lake $\left(41^{\circ} 53^{\prime} 42^{\prime \prime} \mathrm{N}, 12^{\circ} 32^{\prime} 20^{\prime \prime} \mathrm{E} ; 7 \mathrm{~m}\right.$ depth). According to the single hose method (TAssi \& RouwET, 2014), a small diameter $(6 \mathrm{~mm})$ Rilsan tube, lowered at the sampling depth and connected to a $100 \mathrm{~mL}$ syringe equipped with a three-way Teflon valve, was used to pump up the water. After the displacement of a water volume at least twice the inner volume of the tube, one unfiltered $(0.45 \mu \mathrm{m})$ and two filtered-acidified (with $1 \% \mathrm{HCl}$ and ultrapure $\mathrm{HNO}_{3}$, respectively) water samples were collected in polyethylene bottles for the analysis of major anions $\left(\mathrm{F}^{-}, \mathrm{Cl}^{-}, \mathrm{SO}_{4}{ }^{2-}, \mathrm{NO}_{3}\right.$ and $\left.\mathrm{NO}_{2}^{-}\right)$, cations $\left(\mathrm{Ca}^{2+}, \mathrm{Mg}^{2+}, \mathrm{NH}_{4}^{+}, \mathrm{Na}^{+}\right.$and $\left.\mathrm{K}^{+}\right)$, and trace elements ( $\mathrm{Al}, \mathrm{V}, \mathrm{Cr}, \mathrm{Fe}, \mathrm{As}, \mathrm{Sr}, \mathrm{Pb}, \mathrm{Mn}, \mathrm{B})$, respectively. Major elements were analysed by Ion-Chromatography (IC, Dionex ICS-900 Thermo Scientific, analytical error 5\%), whereas trace elements were determined by Inductively Coupled Plasma Mass Spectrometry (ICP-MS; Agilent 7500ce, analytical error $10 \%$ ). The $\mathrm{D} /{ }^{1} \mathrm{H}$ and ${ }^{18} \mathrm{O} /{ }^{16} \mathrm{O}$ ratios of water (expressed as $\delta \mathrm{D}-\mathrm{H}_{2} \mathrm{O}$ and $\mathrm{d}^{18} \mathrm{O}-\mathrm{H}_{2} \mathrm{O} \% \mathrm{~V}$-SMOW) were determined on unfiltered water samples by Isotope Ratio Mass Spectrometry (IRMS). A TC-EA peripheral interfaced by means of a ConFloIV with Thermo Delta XP mass spectrometer was used for hydrogen isotopes. Oxygen isotopes measurements were carried out by using a Gas Bench peripheral coupled with a Thermo Delta V mass spectrometer. IRMS analytical error was $\pm 0.1 \%$ o for $\mathrm{d}^{18} \mathrm{O}$ and below $\pm 1 \%$ for $\delta \mathrm{D}$. The ${ }^{87} \mathrm{Sr} /{ }^{86} \mathrm{Sr}$ ratio of water was determined on unfiltered water samples by a MultiCollector ICPMS (MC-ICP-MS) coupled to a $123 \mathrm{~nm}$ Laser Ablation (LA) system following the procedure described by LugLI et alii (2017).

Water samples for the determination of dissolved gases were collected in $125 \mathrm{~mL}$ glass flasks equipped with a rubber septum. Dissolved gas chemistry $\left(\mathrm{H}_{2}, \mathrm{He}, \mathrm{N}_{2}, \mathrm{CH}_{4}\right.$, $\mathrm{CO}_{2}, \mathrm{Ne}$ ) was determined in the free-gas phase, formed in the headspace of the sampling flasks by injecting $\mathrm{Ar}$ through the rubber septum, by gas chromatography (GC) using a Varian CP-4900 Micro gas chromatograph equipped with two TCD detectors and $\mathrm{Ar}$ as carrier gas (CAPASso \& Inguaggiato, 1998). The dissolved gas concentrations (expressed in bar) were calculated from the composition of the headspace gas on the basis of the solubility coefficients of each gas compound (WHITFIELD, 1978). Analytical error for $\mathrm{GC}$ was $<5 \%$. On the same sampling flasks, the ${ }^{13} \mathrm{C} /{ }^{12} \mathrm{C}$ isotopic ratio of Total Dissolved Inorganic Carbon (TDIC), expressed as $\delta^{13} \mathrm{C}$-TDIC \%o VPDB, was analyzed by Mass Spectrometry (MS: Finnigan Delta plus XP) following the procedure described by SALATA et alii (2000). The analytical error for MS was $\pm 0.1 \%$.

\section{DisSOLVED ORGANIC CARBON (DOC)}

The organic matter in the water was filtered onto muffled GF/F Whatman filters and collected in acid pre- 

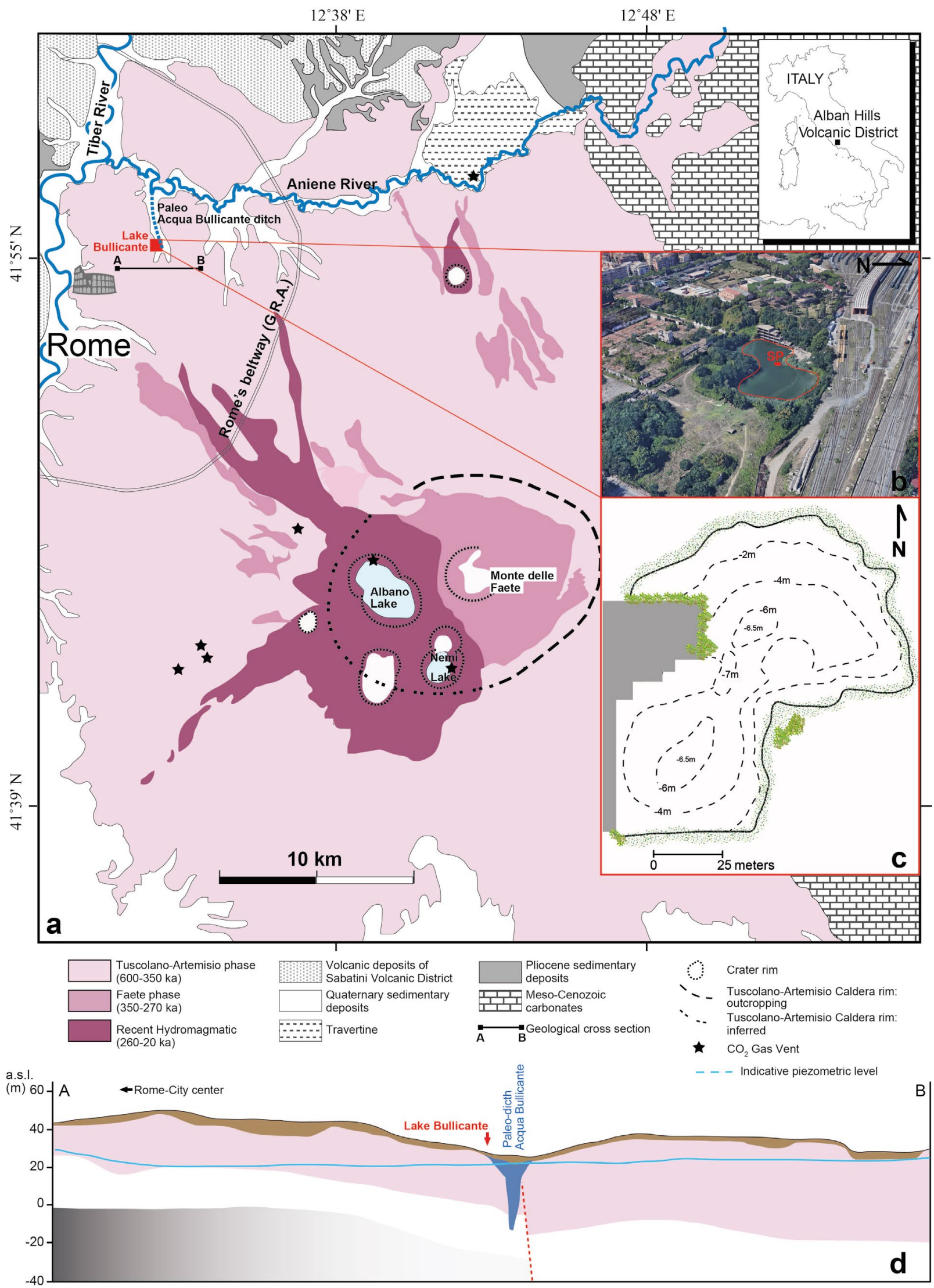

Fig. 2 - a) Simplified geological map of the AHVD (modified from MARRA et alii, 2009) and location of the Lake Bullicante. The three phases of volcanic activity are highlighted. b) Zoomed view on the lake, where the sampling point (SP) is also shown. c) Bathymetric map of the Lake Bullicante d) Simplified geological section (modified from CAPELLI et alii, 2008) passing through the study area; for the legend, see the one reported above the profile, with the exception of: brown colour for man-made fill terrains; blue for alluvia, and dashed red line for inferred fault. 
washed $20 \mathrm{ml}$ vials. Dissolved organic carbon (DOC) in acidified samples ( $\mathrm{HCl}$, Fluka Suprapur) was measured using Shimadzu TOC Analyzer.

Absorbance at $254 \mathrm{~nm}$, scan in the range 270-300 $\mathrm{nm}$ and 350-450 nm were carried out using UV-VIS Spectrophotometer Perkin Elmer Lambda 25. These measurements were used to calculate SUVA $_{254}$ index and Spectra Slope ratio based on spectral slope $\mathrm{S} 1_{270-300}$ and $\mathrm{S} 2_{350-450^{\circ}}$

Specific UV Absorbance (SUVA) is defined as the UV absorbance of a water sample at $254 \mathrm{~nm}$ normalized for dissolved organic carbon (DOC) concentration. Its value is strongly correlated to the aromaticity of dissolved organic matter (WEISHAAR et alii, 2003)

$$
S U V A_{254}=\frac{A b s_{254} * \ln 10}{D O C * 0.01}
$$

where DOC concentration is expressed in $\mathrm{mg} / \mathrm{L}, 0.01$ is the conversion factor to transform optical path from $\mathrm{cm}$ to $\mathrm{m}$ and $\mathrm{Abs}_{254}{ }^{*} \ln 10$ corresponds to $a$ the Napierian adsorption coefficient $\left(\mathrm{m}^{-1}\right)$.

The spectral slope $\left(\mathrm{S}, \mathrm{nm}^{-1}\right)$ has been derived from DOC absorption spectra by fitting the absorption data to the equation:

$$
a_{\lambda}=a_{\lambda_{r e f}} e^{-S\left(\lambda-\lambda_{r e f}\right)}
$$

where $a$ is the Napierian absorption coefficient $\left(\mathrm{m}^{-1}\right), \lambda$ is the wavelength (nm) and $\lambda_{\text {ref }}$ is the reference wavelength (nm) (TwARDOWSKI et alii, 2004). Two distinct spectral slope regions (275-295 $\mathrm{nm}$ and 350-400 nm) within logtransformed absorption spectra were used to evaluate organic matter transformation $\left(\mathrm{S}_{1}\right.$ and $\mathrm{S}_{2}$ ) (HeLms et alii, 2008). The ratio $S_{R}$ of the slope $S_{1}$ and $S_{2}$ is then calculated:

$$
S_{R}=\frac{S 1}{S 2}=\frac{\text { slope } 275-295}{\text { slope } 350-400}
$$

SR provides information about molecular size, origin and photodegradation. Thus, high proportion of the DOM molecular fraction with low molecular weight and photodegradation determine increase of $S_{R}$ values. For the analysis of microbial community, lake waters $(50 \mathrm{~mL})$ were collected at 9 depths. Moreover, aliquots $(250 \mathrm{~mL})$ were collected at 5 depths $(0,1,3,5,7 \mathrm{~m}$ depth), fixed on-site with formaldehyde solution $(37 \% \mathrm{w} / \mathrm{v}$, Sigma Aldrich; final concentration $1 \%$ ), and stored at $4{ }^{\circ} \mathrm{C}$ for $2 \mathrm{~h}$.

\section{Microbiological SAMPLing AND ANALYSES}

To assess the abundance of Bacteria and Archaea, subaliquots of $5-10 \mathrm{~mL}$ were filtered at low vacuum levels (<0.2 bar) onto $0.2 \mu \mathrm{m}$ pore-size polycarbonate filters (type GTTP; diameter, 47 mm; Millipore, Eschborn, Germany). Filters were stored at $-20^{\circ} \mathrm{C}$ until further processing. Filter sections were stained with DAPI at a final concentration of $1 \mu \mathrm{g} / \mathrm{mL}$ to quantify the total Prokaryotes. Community composition was assessed by fluorescence in situ Hybridization Catalyzed Reported Deposition (CARDFISH) as described in TASSI et alii (2018). In particular, rRNA-target Horseradish peroxidase (HRP) labeled oligonucleotidic probes (Biomers, Ulm, Germany) were used to target Bacteria (EUB338 I-III), and Archaea (ARCH915).

The abundance of total prokaryotes and pigmented phytoplanktonic microorganisms (i.e., Cyanobacteria, pico- and nano-Eukaryotes) were determined by the Flow Cytometer A50-micro (Apogee Flow System, Hertfordshire, UK), equipped with a $20 \mathrm{~mW}$ Solid State Blue Laser $(488 \mathrm{~nm})$ and a $16 \mathrm{~mW}$ Solid State UV laser $(375 \mathrm{~nm})$. The light scattering signals (forward and side light scatter named FSC and SSC, respectively), red fluorescence $(>610 \mathrm{~nm})$, orange fluorescence $(590 / 35 \mathrm{~nm})$, and blue fluorescence $(430-470 \mathrm{~nm})$ were acquired and considered for the direct identification and quantification of distinct microbial groups by following harmonized protocols (GASOL \& MORÁN, 2015). Total prokaryotes were quantified by following the staining procedure with SYBR Green I (1:10000 dilution; Life Technologies, code S7563). Thresholding was set on the green channel, and gating strategy was manually adjusted to exclude most of the unspecific signals according to negative unstained controls. Cyanobacteria, pico- and nano-Eukaryotes were characterized and distinguished according to their pigmentation (i.e., reflecting on different intensities of autofluorescence signals collected at the orange and red channels) and size (i.e., proportionally related to light scatter signals). Thresholding was set on the red channel in order to exclude most of the unspecific signals according to $0.2-\mu \mathrm{m}$ filtered control water samples. The gating strategy was manually adjusted on the density plots of SSC versus Red and of Orange versus Red channels. The volumetric absolute counting was carried out in density plots of SSC versus blue channel. Data handling and visualization were performed by the Apogee Histogram Software (v89.0).

\section{RESULTS}

\section{WATER TEMPERATURE, EC, PH AND DISSOLVEd $\mathrm{O}_{2}$}

Temperature, $\mathrm{pH}, \mathrm{EC}$ and dissolved $\mathrm{O}_{2}$ concentrations measured along the vertical profiles of Lake Bullicante are shown in Fig. 3a-d. During the winter survey, water temperature $\left(\sim 15^{\circ} \mathrm{C}\right)$ did not display significant variation with depth. In the summer, the lake surface was warm (up to $28^{\circ} \mathrm{C}$ ) and a thermocline was recognized at 1-4 $\mathrm{m}$ depth (Fig. 3a) separating a relatively warm epilimnion $\left(28^{\circ} \mathrm{C}\right)$ from a cold hypolimnion $\left(11^{\circ} \mathrm{C}\right)$. The $\mathrm{pH}$ followed a similar vertical pattern to temperature: it was relatively constant in the winter $(\sim 7.5)$, whereas in the summer, it showed a $S$ shape profile, with high values (between 8 and 9) up to $2 \mathrm{~m}$ depth, then progressively decreasing to values around 7 towards the bottom (Fig. 3b). The EC was constant $(\sim 770 \mu \mathrm{S} / \mathrm{cm})$ in the winter along the entire vertical profile (Fig. 3c). In June, the EC profile was marked by three chemoclines, the shallowest one in correspondence of the thermocline, the main one at 2-6 $\mathrm{m}$ depth and the third one at $7 \mathrm{~m}$ depth. Dissolved $\mathrm{O}_{2}$ concentrations, during the winter, did not display significant variation with depth $(\sim 0.12 \pm 0.3 \mathrm{mg} / \mathrm{L})$, whereas in the summer it had a strong decrease with depth, disappearing immediately below $2 \mathrm{~m}$ depth (Fig. 3d). 

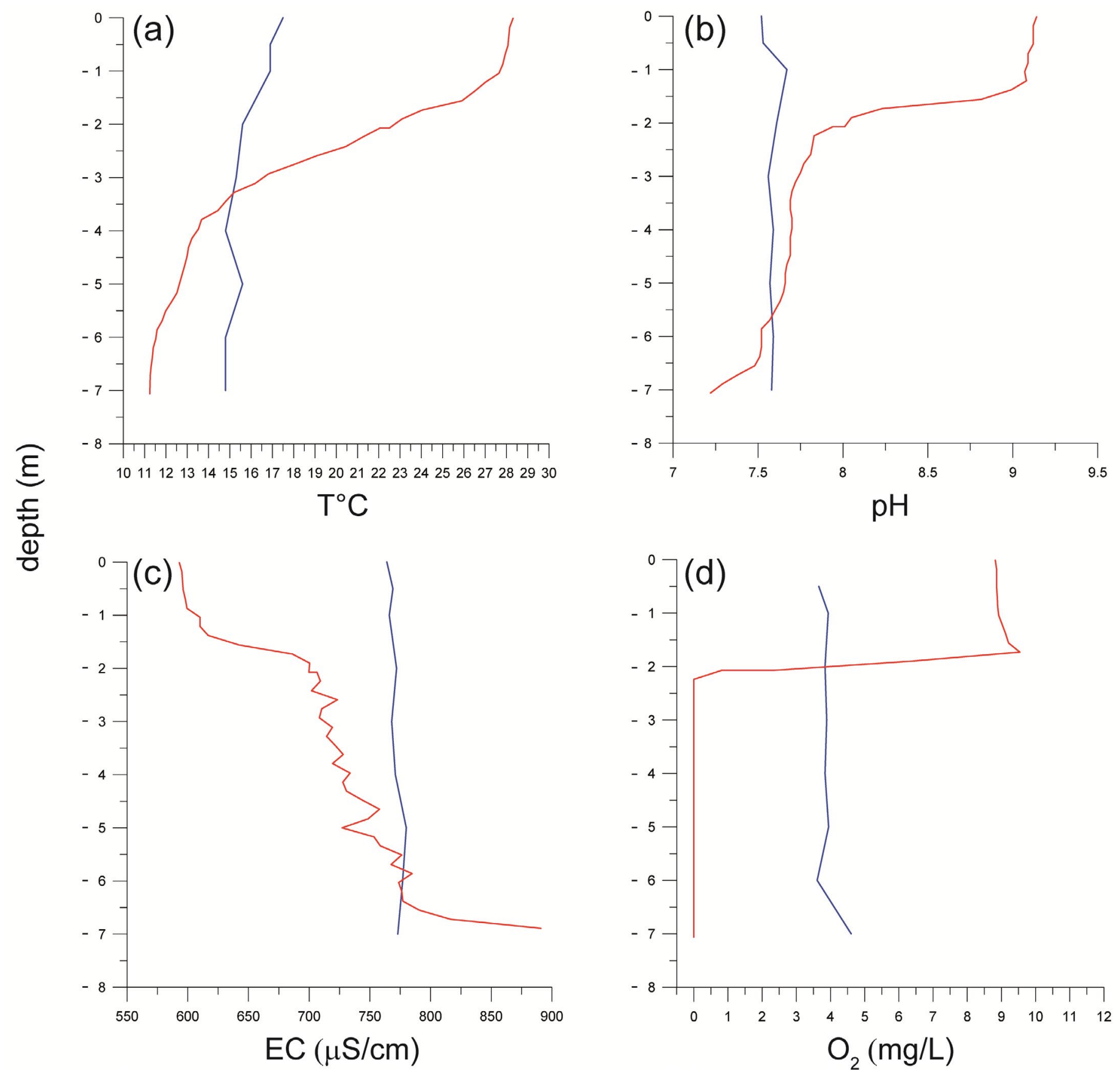

Fig. 3 - Winter (blue) and summer (red)vertical profiles along the Lake Bullicante water column of a) water temperature $\left({ }^{\circ} \mathrm{C}\right)$; b) $\mathrm{pH}$, c) electrical conductivity (EC, in $\mu \mathrm{S} / \mathrm{cm}$ ) and d) dissolved $\mathrm{O}_{2}$ concentration (in $\mathrm{mg} / \mathrm{L}$ ).

\section{CHEMICAL AND ISOTOPIC COMPOSITION OF LAKE WATER AND DISSOLVED GASES}

Thelakewaterwas characterized by total dissolved solids (TDS) up to $704 \mathrm{mg} / \mathrm{L}$ and a $\mathrm{Ca}(\mathrm{Mg})-\mathrm{HCO}_{3}$ composition, and showed relatively constant concentrations of the two major ions $\left(\mathrm{Ca}^{2+}\right.$ and $\mathrm{HCO}_{3}{ }^{-}$concentrations up to 72 and $415 \mathrm{mg} / \mathrm{L}$, respectively) from the lake surface to the bottom (Fig. 4a-b, Tab. 1). Concentrations of $\mathrm{F}^{-}, \mathrm{Cl}^{-}, \mathrm{SO}_{4}{ }^{2-}, \mathrm{Na}^{+}$, $\mathrm{K}^{+}$and $\mathrm{Mg}^{2+}$ were up to $2.3,37,46,35,45$ and $26 \mathrm{mg} / \mathrm{L}$, respectively and were nearly constant through the vertical lake profile (Fig.4b-d, Tab. 1). Nitrogen species showed a different behavior. As $\mathrm{NH}_{4}^{+}$concentrations were nearly constant from the lake surface to the bottom ( 0.44 to 0.59 $\mathrm{mg} / \mathrm{L}), \mathrm{NO}_{3}{ }^{-}$ranged from 6 to $10 \mathrm{mg} / \mathrm{L}$ in the upper $4 \mathrm{~m}$ and decreasing to $0.26 \mathrm{mg} / \mathrm{L}$ at $5 \mathrm{~m}$ depth (Fig. $4 \mathrm{~d}$ ), whereas $\mathrm{NO}_{2}$ - showed a reverse trend, being lower in the upper $4 \mathrm{~m}$ (up to $2.9 \mathrm{mg} / \mathrm{L}$ ) and higher towards the lake bottom (up to $6.3 \mathrm{mg} / \mathrm{L}$ ).

As far as minor and trace elements concentration is concerned, relatively constant concentrations of B, Sr (up to 0.12 and $1.0 \mu \mathrm{g} / \mathrm{L}$, respectively) $\mathrm{V}, \mathrm{Cr}, \mathrm{Fe}, \mathrm{Mn}, \mathrm{As}$ and $\mathrm{Pb}$ (up to $22,1.3,5.2,53,12$ and $0.38 \mu \mathrm{g} / \mathrm{L}$, respectively) were recorded, whereas the aluminum abruptly decreased from 13 to $3.1 \mu \mathrm{g} / \mathrm{L}$ between 0 and $1 \mathrm{~m}$ depth, then irregularly ranged from 0.51 to $3.1 \mu \mathrm{g} / \mathrm{L}$ in the interval from 1 to $4 \mathrm{~m}$ 

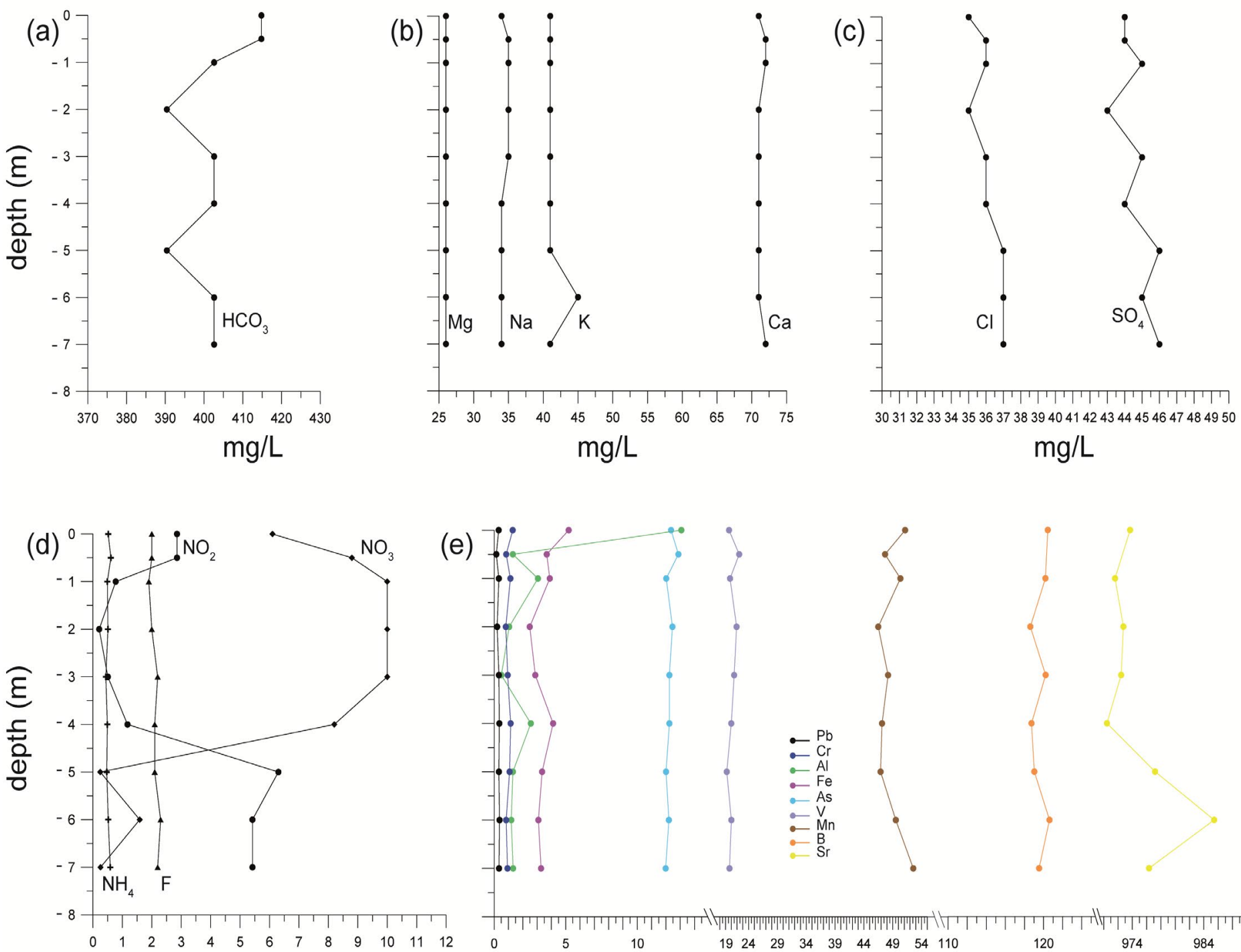
$\mathrm{mg} / \mathrm{L}$

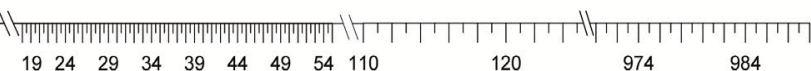

$\mu \mathrm{g} / \mathrm{L}$
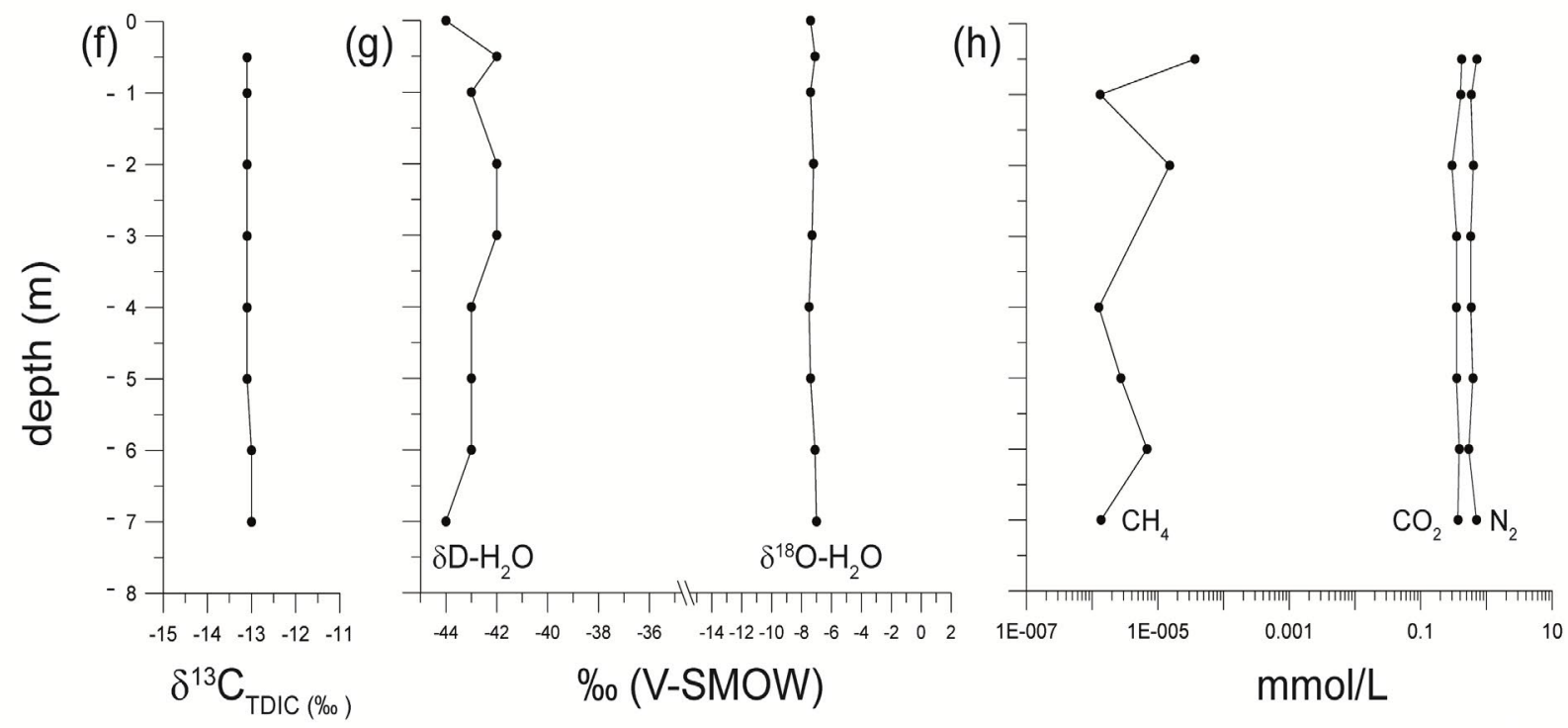

Fig. 4 - Vertical profile along the Lake Bullicante water column of a) $\mathrm{HCO}$ concentration; b) $\mathrm{Mg}, \mathrm{Na}, \mathrm{K}$ and $\mathrm{Ca}$ concentrations; c) $\mathrm{Cl}$ and $\mathrm{SO}$ concentrations; d) $\mathrm{NO}_{3}, \mathrm{NO}_{2}, \mathrm{NH}_{4}$ and $\mathrm{F}$ concentrations; e) trace element $(\mathrm{Pb}, \mathrm{Cr}, \mathrm{Al}, \mathrm{Fe}, \mathrm{As}, \mathrm{V}, \mathrm{Mn}, \mathrm{B}$ and $\mathrm{Sr})$ concentrations; f) $\delta{ }^{13} \mathrm{C}-\mathrm{CO}_{2}$ value (\%o vs. V-PDB), g) $\delta \mathrm{D}-\mathrm{H}_{2} \mathrm{O}$ and $\delta^{18} \mathrm{O}-\mathrm{H}_{2} \mathrm{O}$ values and $\mathrm{h}$ ) dissolved $\mathrm{CH}_{4}, \mathrm{CO}_{2}$ and $\mathrm{N}_{2}$ concentrations. 
TABLE 1

Chemical composition of the water sampled from the Lake Bullicante. Sampling depth (in $\mathrm{m}$ ), temperature $\left(\mathrm{T}\right.$, in ${ }^{\circ} \mathrm{C}$ ), $\mathrm{pH}$, Total Dissolved Solids (TDS, in $\mathrm{mg} / \mathrm{L}$ ) and concentrations of the main ions $\left(\mathrm{HCO}_{3}^{-}, \mathrm{F}^{-}, \mathrm{Cl}^{-}, \mathrm{NO}_{2}^{-}, \mathrm{NO}_{3}^{-}, \mathrm{SO}_{4}^{2-}, \mathrm{Ca}^{2+}\right.$, $\mathrm{Mg}^{2+}, \mathrm{Na}^{+}, \mathrm{K}^{+}, \mathrm{NH}_{4}^{+}, \mathrm{PO}_{4}{ }^{3-}$ in $\mathrm{mg} / \mathrm{L}$ ) and traces elements (Al, $\mathrm{V}, \mathrm{Cr}, \mathrm{Fe}, \mathrm{As}, \mathrm{Sr}, \mathrm{Cd}, \mathrm{Pb}, \mathrm{Mn}$ and $\mathrm{B}$, in $\mu \mathrm{g} / \mathrm{L}$ ) are reported. The $\boldsymbol{\delta}^{18} \mathrm{O}-\mathrm{H}_{2} \mathrm{O}$ (\%o vs. V-SMOW), $\boldsymbol{\delta} \mathrm{D}-\mathrm{H}_{2} \mathrm{O}$ (\%o vs. V-SMOW), and $\boldsymbol{\delta}^{13} \mathrm{C}$-TDIC (in \%o vs. V-PDB) and ${ }^{87} \mathrm{Sr} /{ }^{86} \mathrm{Sr}$ values are also reported; nd: not determined.

\begin{tabular}{|c|c|c|c|c|c|c|c|c|c|c|c|c|c|c|c|}
\hline Depth & $\mathbf{T}$ & pH & TDS & $\mathrm{HCO}_{3}^{-}$ & $\mathbf{F}^{-}$ & $\mathrm{Cl}^{-}$ & $\mathrm{NO}_{2}^{-}$ & $\mathrm{NO}_{3}^{-}$ & $\mathrm{SO}_{4}{ }^{2-}$ & $\mathbf{C a}^{2+}$ & $\mathbf{M g}^{2+}$ & $\mathrm{Na}^{+}$ & $\mathbf{K}^{+}$ & $\mathbf{N H}_{4}{ }^{+}$ & $\mathrm{PO}_{4}{ }^{3-}$ \\
\hline 0 & 17.8 & 7.5 & 704 & 415 & 2.0 & 35 & 2.9 & 6.1 & 44 & 71 & 26 & 34 & 41 & 0.52 & $<0.10$ \\
\hline 1 & 16.9 & 7.7 & 697 & 403 & 1.9 & 36 & 0.77 & 10 & 45 & 72 & 26 & 35 & 41 & 0.49 & $<0.10$ \\
\hline 2 & 15.6 & 7.6 & 681 & 390 & 2.0 & 35 & 0.21 & 10 & 43 & 71 & 26 & 35 & 41 & 0.51 & $<0.10$ \\
\hline 3 & 15.3 & 7.6 & 696 & 403 & 2.2 & 36 & 0.51 & 10 & 45 & 71 & 26 & 35 & 41 & 0.44 & $<0.10$ \\
\hline 4 & 14.8 & 7.6 & 693 & 403 & 2.1 & 36 & 1.2 & 8.2 & 44 & 71 & 26 & 34 & 41 & 0.49 & $<0.10$ \\
\hline 5 & 15.6 & 7.6 & 681 & 390 & 2.1 & 37 & 6.3 & 0.25 & 46 & 71 & 26 & 34 & 41 & 0.47 & $<0.10$ \\
\hline 6 & 14.8 & 7.6 & 697 & 403 & 2.3 & 37 & 5.4 & 1.6 & 45 & 71 & 26 & 34 & 45 & 0.52 & $<0.10$ \\
\hline 7 & 14.8 & 7.6 & 693 & 403 & 2.2 & 37 & 5.4 & 0.26 & 46 & 72 & 26 & 34 & 41 & 0.59 & $<0.10$ \\
\hline Depth & Al & $\mathbf{V}$ & $\mathrm{Cr}$ & $\mathbf{F e}$ & As & $\mathbf{S r}$ & $\mathbf{P b}$ & Mn & B & $\delta^{13} \mathbf{C}_{\mathrm{TDIC}}$ & & ${ }^{18} \mathrm{O}-\mathrm{H}_{2} \mathrm{C}$ & & $\delta^{18} \mathbf{D}-\mathbf{H}_{2} \mathbf{O}$ & ${ }^{87} \mathrm{Sr} /{ }^{86} \mathbf{S r}$ \\
\hline 0 & 13 & 21 & 1.3 & 5.2 & 12 & 974 & 0.32 & 51 & 120 & -13.1 & & -7.4 & & -44 & nd \\
\hline 1 & 3.1 & 21 & 1.1 & 3.9 & 12 & 972 & 0.33 & 50 & 120 & -13.1 & & -7.1 & & -42 & 0.710403 \\
\hline 2 & 1.1 & 22 & 0.81 & 2.5 & 12 & 973 & 0.21 & 46 & 119 & -13.1 & & -7.4 & & -43 & nd \\
\hline 3 & 0.51 & 22 & 0.95 & 2.9 & 12 & 972 & 0.33 & 48 & 120 & -13.1 & & -7.2 & & -42 & nd \\
\hline 4 & 2.6 & 21 & 1.2 & 4.1 & 12 & 970 & 0.36 & 47 & 119 & -13.1 & & -7.3 & & -42 & nd \\
\hline 5 & 1.3 & 20 & 1.1 & 3.4 & 12 & 977 & 0.33 & 47 & 119 & -13.1 & & -7.5 & & -43 & nd \\
\hline 6 & 1.2 & 21 & 0.84 & 3.1 & 12 & 985 & 0.38 & 50 & 121 & -13.0 & & -7.4 & & -43 & nd \\
\hline 7 & 1.3 & 21 & 0.93 & 3.3 & 12 & 976 & 0.34 & 53 & 120 & -13.0 & & -7.1 & & -43 & nd \\
\hline
\end{tabular}

depth and stabilized near $1.3 \mu \mathrm{g} / \mathrm{L}$ towards the lake bottom (Fig. 4e).

The $\delta^{13} \mathrm{C}$-TDIC values were constant with depth at the value of $-13 \%$ vs. V-PDB (Fig. 4f). The $\delta^{18} \mathrm{O}-\mathrm{H}_{2} \mathrm{O}$ and $\delta D-$ $\mathrm{H}_{2} \mathrm{O}$ values varied in a narrow range from -7.0 to $-7.5 \%$ and from -42 to $-44 \%$ vs. V-SMOW, respectively (Fig. $4 \mathrm{~g}$ ). No clear trends with depth were observed by these isotopic parameters. $\mathrm{The}{ }^{87} \mathrm{Sr} /{ }^{86} \mathrm{Sr}$ ratio was analyzed at the sampling depth of $1 \mathrm{~m}$ and showed a value of 0.7104 .

The chemical $(\mathrm{mmol} / \mathrm{L})$ and isotopic composition $\left(\delta^{13} \mathrm{C}\right.$ $\mathrm{CO}_{2}$ ) of dissolved gases is reported in Tab. 2. Nitrogen and $\mathrm{CO}_{2}$ were largely dominant in the lake profile $\left(\mathrm{N}_{2}\right.$ from 0.54 to $0.72 \mathrm{mmol} / \mathrm{L}, \mathrm{CO}_{2}$ from 0.35 to $0.42 \mathrm{mmol} / \mathrm{L}$; Fig. $4 \mathrm{~h}$ ), whereas $\mathrm{O}_{2}$ and $\mathrm{CH}_{4}$ were relatively lower (from 0.11 to 0.14 $\mathrm{mol} / \mathrm{L}$ and from $1.3 \times 10^{-6}$ to $3.7 \times 10^{-5} \mathrm{mmol} / \mathrm{L}$, respectively). None of them showed clear trend with depth. He and $\mathrm{H}_{2}$ were detected only at the lake bottom, with concentrations of $3.9 \times 10^{-6}$ and $5.7 \times 10^{-6} \mathrm{mmol} / \mathrm{L}$, respectively.

The $\delta^{13} \mathrm{C}$ values of dissolved $\mathrm{CO}_{2}$ were calculated from the $\delta^{13} \mathrm{C}$-TDIC values using the empirical equation of ZHANG et alii (1995), as follows:

$\delta^{13} \mathrm{C}-\mathrm{CO}_{2}(\mathrm{~g})=\delta^{13} \mathrm{C}_{\mathrm{TDIC}}-\frac{\mathrm{H}_{2} \mathrm{CO}_{3}}{\mathrm{TDIC}} \varepsilon\left(\mathrm{H}_{2} \mathrm{CO}_{3}-\mathrm{CO}_{2}\right)-\frac{\mathrm{HCO}_{3}^{-}}{\mathrm{TDIC}} \varepsilon\left(\mathrm{HCO}_{3}^{-}-\mathrm{CO}_{2}\right)-\frac{\mathrm{CO}_{3}^{2-}}{\mathrm{TDIC}}\left(\mathrm{CO}_{3}^{2-}-\mathrm{CO}_{2}\right)$

where the equilibrium molar ratios of aqueous carbon species at sampling temperature and $\mathrm{pH}$, used in equation showed above, were computed with the PHREEQC code
(Parkhurst \& Appelo, 2013), whereas the value given by Deuser \& Degens (1967) and Mook et alii (1974) was used for the isotope fractionation factor $(\varepsilon)$ between gaseous $\mathrm{CO}_{2}$ and dissolved $\left(\mathrm{CO}_{2 \mathrm{aq}}\right)$. The $\mathrm{\delta}^{13} \mathrm{C}-\mathrm{CO}_{2}$ values ranged from -21.2 to $-21.6 \%$ V-PDB (Tab. 2).

\section{TABLE 2}

Main dissolved gases $\left(\mathrm{N}_{2}, \mathrm{O}_{2}, \mathrm{CH}_{4}, \mathrm{CO}_{2}, \mathrm{He}, \mathrm{H}_{2}\right.$, in $\mathrm{mmol} / \mathrm{L})$ from Lake Bullicante. Sampling depth ( $\mathrm{m})$ and isotopic composition of dissolved $\mathrm{CO}_{2}\left(\delta^{13} \mathrm{C}-\mathrm{CO}_{2}\right.$ in \%o vs.

$\mathrm{V}-\mathrm{PDB}$ ) are also reported; bdl: below detection limit.

\begin{tabular}{cccccccc}
\hline Depth & $\mathbf{N}_{2}$ & $\mathbf{O}_{2}$ & $\mathbf{C H}_{4}$ & $\mathbf{C O}_{2}$ & $\mathbf{H e}$ & $\mathbf{H}_{2}$ & $\boldsymbol{\delta}^{\mathbf{1 3}} \mathbf{C}-\mathbf{C O}_{2}$ \\
\hline 0.5 & 0.72 & 0.11 & $3.7 \mathrm{E}-05$ & 0.42 & bdl & bdl & -21.2 \\
1 & 0.63 & 0.12 & $1.5 \mathrm{E}-05$ & 0.41 & bdl & bdl & -21.3 \\
2 & 0.58 & 0.12 & bdl & 0.35 & bdl & bdl & -21.6 \\
3 & 0.59 & 0.12 & $1.3 \mathrm{E}-06$ & 0.35 & bdl & bdl & -21.6 \\
4 & 0.63 & 012 & $2.7 \mathrm{E}-06$ & 0.35 & bdl & bdl & -21.6 \\
5 & 0.54 & 0.12 & $6.9 \mathrm{E}-06$ & 0.35 & bdl & bdl & -21.5 \\
6 & 0.71 & 0.11 & $1.4 \mathrm{E}-06$ & 0.39 & bdl & bdl & -21.5 \\
7 & 0.63 & 0.14 & $1.5 \mathrm{E}-05$ & 0.37 & $3.9 \mathrm{E}-06$ & $5.7 \mathrm{E}-06$ & -21.5 \\
\hline
\end{tabular}




\section{Organic Matter}

Mean dissolved organic carbon (DOC) content in Lake Bullicante was $15.3 \pm 9.6 \mathrm{mg} / \mathrm{L}$ with a decreasing trend with depth (Tab. 3) and a maxima at $0.5 \mathrm{~m}$ and a minima at the bottom (Fig.5a). Spectral slope ratio $\left(\mathrm{S}_{\mathrm{R}}\right)$ profile resembled DOC trend. All values, except 1.68 at $0.5 \mathrm{~m}$ depth, were below $1\left(\mathrm{~S}_{2}>\mathrm{S}_{1}\right)$ and ranging from 0.54 to 0.9 (Fig. 5b). Calculated SUVA $_{254}$ values decreased from 0.96 to 0.72 between 1 and $5 \mathrm{~m}$ depth and then increased to 1.75 at the bottom of the lake (Fig. 5c).

The total microbial load in sampled waters was generally high. The prokaryotic abundance ranged between $1 \times 10^{7}$ and $2 \times 10^{7}$ cells $/ \mathrm{ml}$, with microscopy and flow cytometry showing consistently similar results and patterns. The occurrence of pigmented phytoplanktonic microorganisms was in the range of values reported for eutrophic lake waters (Cyanobacteria $=0.6-1.1 \times 10^{5}$ cells $/ \mathrm{ml}$; Pico-Eukaryotes $=7.6-9.5 \times 10^{3}$ cells $/ \mathrm{ml}$; NanoEukaryotes $=1.1-6.1 \times 10^{2}$ cells $/ \mathrm{ml}$ ) without any consistent differences along the water column (Fig. 5d-g). CARDFISH analysis showed that Bacteria represented 65\% -75\% of total DAPI stained cells, while Archaea 6\% - 8\%.

\section{DISCUSSION}

Relatively low TDS (<1000 mg/L) and $\mathrm{Ca}-\mathrm{HCO}_{3}$ composition are typical features of groundwater hosted in the volcanic aquifers of the Roman Magmatic Province and Roman area (CHIOdini \& Frondini, 2001; CinTI et alii. 2017; PIzzino, 2015). The chemical composition of waters from wells located near Lake Bullicante (Pizzino, 2015) (Fig. 6a-
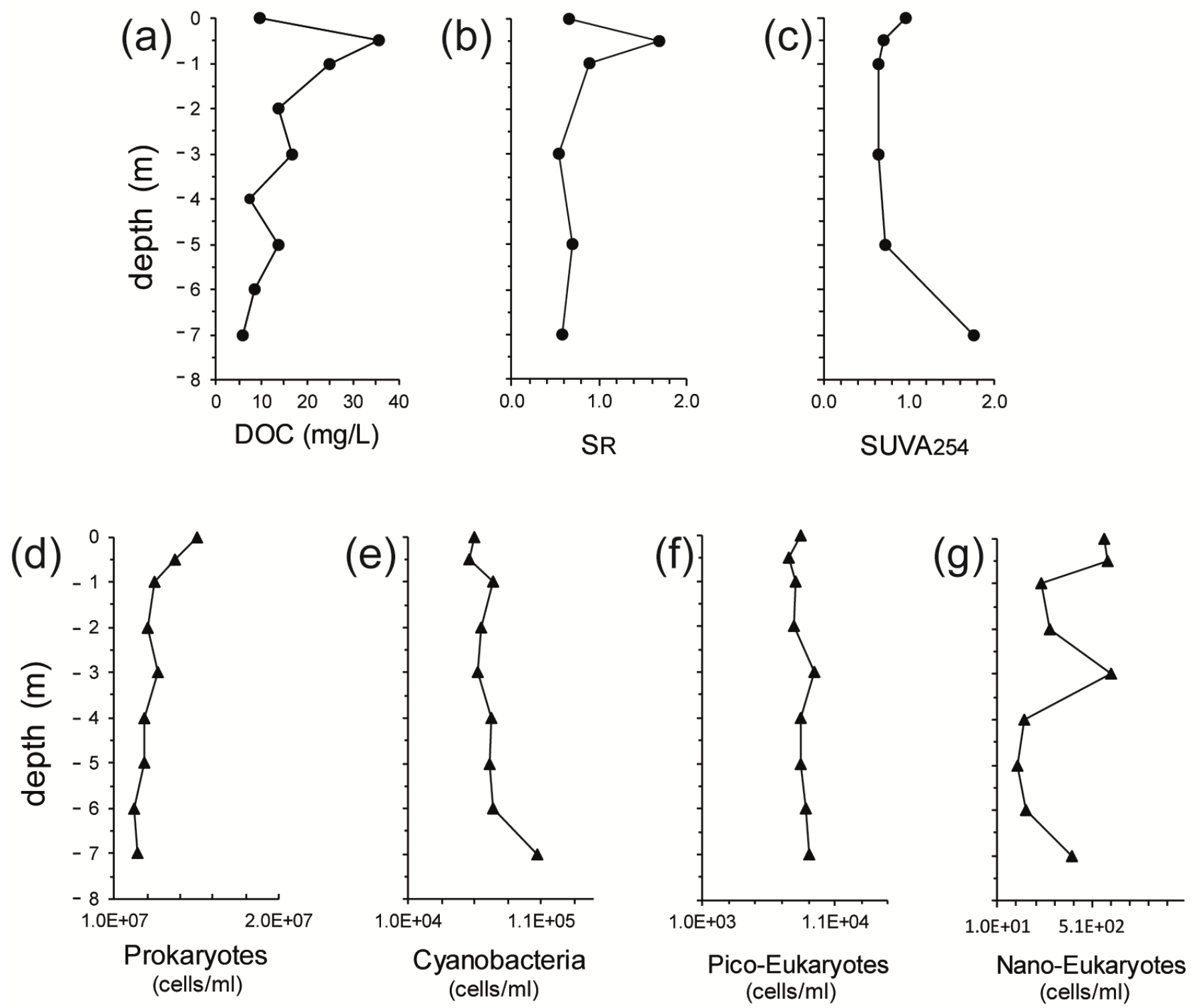

Fig. 5 - Vertical profile along the Lake Bullicante water column of a) dissolved organic carbon (DOC); b) spectra slope ratio (SR) based on spectral slope $\mathrm{S}_{270-300}$ and $\mathrm{S} 2_{350-450}$; c) specific UV absorbance $\left(\mathrm{SUVA}_{254}\right.$ ) of the water sample at 254 wavelength; d) abundance of prokaryotes.; e-g) occurrence of pigmented phytoplanktonic microorganisms (Cyanobacteria, Pico-Eukaryotes, Nano-Eukaryotes). 
TABLE 3

Microbial composition in water samples from the Lake Bullicante. Sampling depth (in m), dissolved organic carbon (DOC, mg/L), spectral slope ration $\left(\mathrm{S}_{\mathrm{R}}\right)$, absorbance at $254 \mathrm{~nm}\left(\mathrm{SUVA}_{254}\right)$, and Prokaryotes, Cyanobacteria, pico- and nano-Eukaryotes abundances (in Cells $/ \mathrm{mL}$ ) are reported; nd: not determined.

\begin{tabular}{cccccccc}
\hline Depth & DOC & $\mathbf{S}_{\mathbf{R}}$ & SUVA $_{\mathbf{2 5 4}}$ & Prokaryotes & Cyanobacteria & PicoEukaryotes & NanoEukaryotes \\
\hline 0 & 9.7 & 0.65 & 0.96 & $1.50 \mathrm{E}+07$ & $5.95 \mathrm{E}+04$ & $8.44 \mathrm{E}+03$ & $5.77 \mathrm{E}+02$ \\
0.5 & 37.5 & 1.68 & 0.70 & $1.37 \mathrm{E}+07$ & $5.62 \mathrm{E}+04$ & $7.57 \mathrm{E}+03$ & $5.98 \mathrm{E}+02$ \\
1 & 25 & 0.90 & 0.65 & $1.24 \mathrm{E}+07$ & $7.43 \mathrm{E}+04$ & $8.03 \mathrm{E}+03$ & $2.40 \mathrm{E}+02$ \\
2 & 13.7 & nd & nd & $1.20 \mathrm{E}+07$ & $6.45 \mathrm{E}+04$ & $7.91 \mathrm{E}+03$ & $2.83 \mathrm{E}+02$ \\
3 & 16.8 & 0.54 & 0.64 & $1.26 \mathrm{E}+07$ & $6.30 \mathrm{E}+04$ & $9.48 \mathrm{E}+03$ & $6.14 \mathrm{E}+02$ \\
4 & 7.5 & nd & nd & $1.18 \mathrm{E}+07$ & $7.23 \mathrm{E}+04$ & $8.36 \mathrm{E}+03$ & $1.53 \mathrm{E}+02$ \\
5 & 13.8 & 0.70 & 0.72 & $1.18 \mathrm{E}+07$ & $7.10 \mathrm{E}+04$ & $8.48 \mathrm{E}+03$ & $1.11 \mathrm{E}+02$ \\
6 & 8.3 & nd & nd & $1.12 \mathrm{E}+07$ & $7.40 \mathrm{E}+04$ & $8.79 \mathrm{E}+03$ & $1.63 \mathrm{E}+02$ \\
7 & 5.7 & 0.58 & 1.75 & $1.14 \mathrm{E}+07$ & $1.07 \mathrm{E}+05$ & $9.10 \mathrm{E}+03$ & $4.02 \mathrm{E}+02$ \\
\hline
\end{tabular}
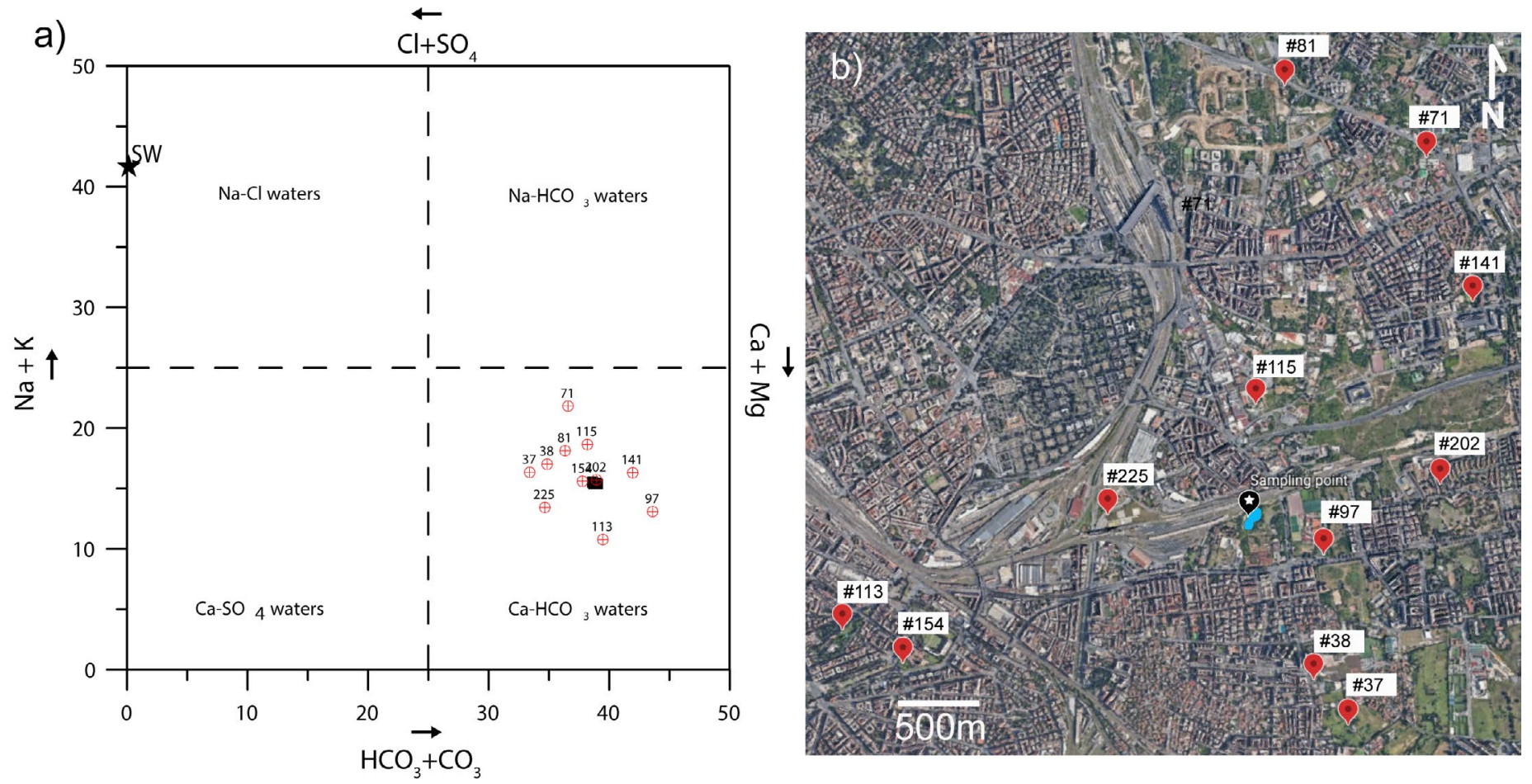

Fig. 6 - a) Langelier-Ludwig square diagram and comparison between the lake water (black squares) and the waters from wells (red circles) from Pizzino (2015); b) location of the water wells (from \#37 to \#225) nearby the lake (Sampling Point).

b), which are fed by shallow, low-temperature reservoirs hosted within volcanic formations, closely resembles lake water. This suggests that the hydrological circuit feeding the lake is closely related to the volcanic aquifer feeding the wells. This is consistent with the relatively high content of $\mathrm{F}^{-}$and $\mathrm{K}^{+}$of the lake water since volcanic products of the Roman Magmatic Province are typically enriched in these elements (Gambardella et alii, 2005; De Rita et alii, 2011).

As shown in the $\delta^{18} \mathrm{O}$ vs. $\delta \mathrm{D}$ diagram (Fig. 7), where the Global Meteoric Water Line (GMWL; Craig, 1961), the Mediterranean Meteoric Water Line (MMWL; GAT \& GARMI, 1970) and the waters from wells from Pizzino (2015) are reported, the isotopic signature of lake and well waters, is consistent with that of meteoric water, confirming that both of them are related to the same aquifer hosted in the volcanic rocks and fed by a meteoric recharge. For all groundwater, the low-temperature environment is highlighted by the absence of $\delta^{18} \mathrm{O}$ positive shifts.

The aquifer is hosted in the distal Alban Hills volcanic products related to the first phase of volcanic activity. In this regard, the comparison among the ${ }^{87} \mathrm{Sr} /{ }^{86} \mathrm{Sr}$ isotopes ratio of the Alban Hills volcanites (in the range 0.710290.71057 , e.g. BOARI et alii, 2009), the lake and the water collected from a nearby well (\#202, Fig. 6b), shed light on their common origin. This relationship is well shown in Fig. 8 where ${ }^{87} \mathrm{Sr} /{ }^{86} \mathrm{Sr}$ of both rocks and groundwater 


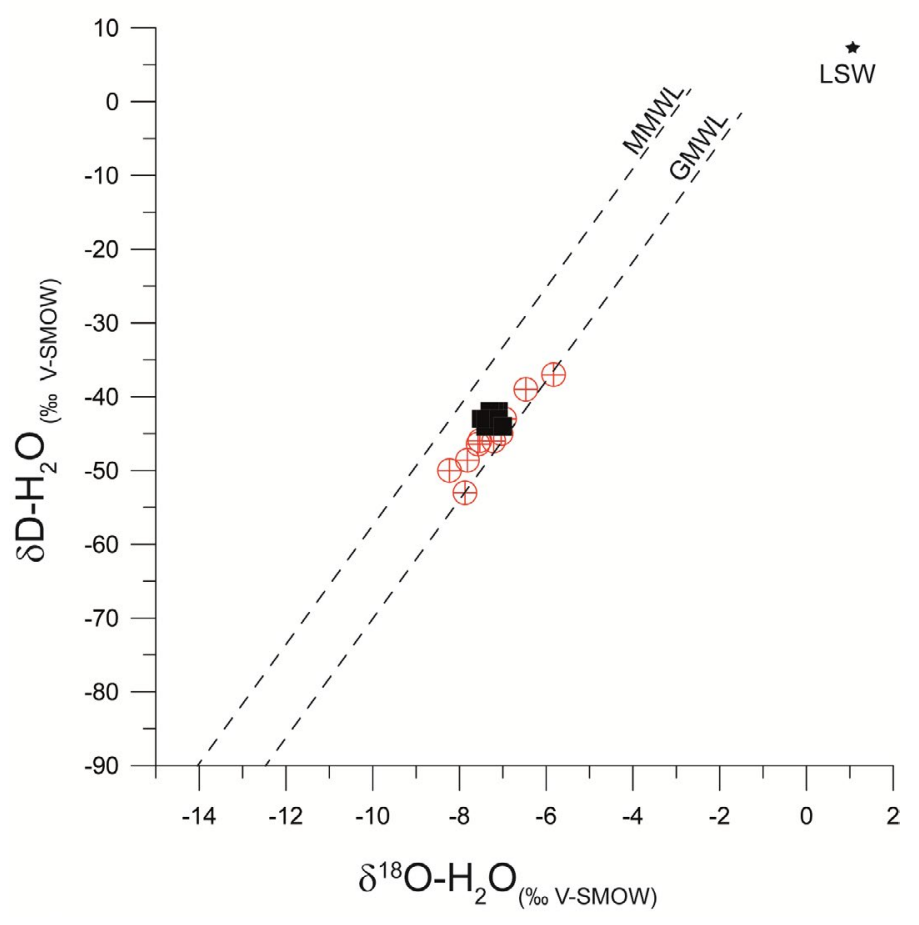

Fig. 7 - $\delta \mathrm{D}-\mathrm{H}_{2} \mathrm{O}$ vs. $\delta^{18} \mathrm{O}-\mathrm{H}_{2} \mathrm{O}$ diagram for Lake Bullicante and waters from neighboring wells from Pizzino (2015). The dashed lines delineate the isotopic domain for Global Meteoric Waters (GMWL $\delta \mathrm{D}=8 \mathrm{~d}^{18} \mathrm{O}+10$; CrAIG, 1961) and that for Mediterranean Meteoric Waters (MMWL; $\delta \mathrm{D}=8 \mathrm{~d}^{18} \mathrm{O}+22 ; \mathrm{G}$ AT \& $\mathrm{C}_{\mathrm{ARMI}}, 1970$ ), respectively. LSW $=$ local seawater. Symbols as in Fig. 6 .

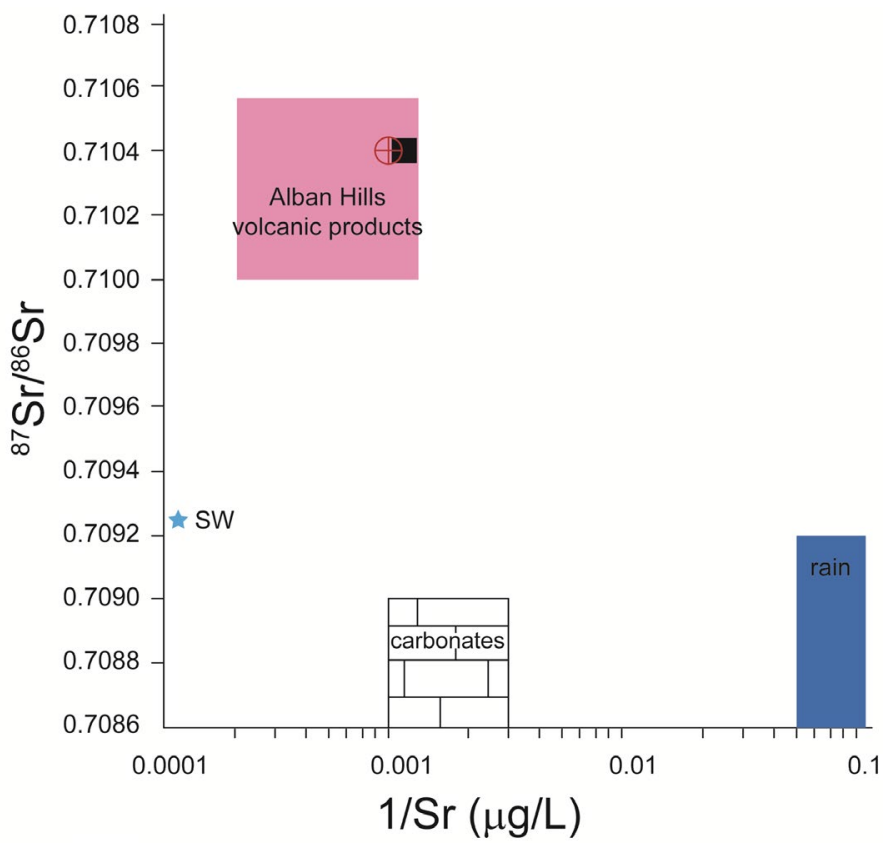

Fig. $8-{ }^{87} \mathrm{Sr} /{ }^{86} \mathrm{Sr}$ vs. $1 / \mathrm{Sr}$ of Lake Bullicante water sample and a water sample from a well taken as representative of the volcanic aquifer (see text). For comparison, ${ }^{87} \mathrm{Sr}{ }^{86} \mathrm{Sr}$ values/ranges of Alban Hills volcanic rocks (e.g. BOARI et alii, 2009), Apennine carbonate rocks (e.g. BARBIERI et alii, 1979), seawater (sw, e.g. VeIzer, 1989) and rainwater (e.g. PEARCE et alii, 2015), are also shown. Symbols as in Fig. 6. are plotted against $1 / \mathrm{Sr}$. Data clearly show that both water (lake and well) have the same isotopic value and lie in the field of the Alban Hills volcanites.

Since lake water chemistry was analyzed during the winter survey, it is not surprising that it does not show significant variations along the vertical profile, both for major and trace elements. An exception is represented by the nitrate and nitrite concentrations, i.e. the significant decrease of $\mathrm{NO}_{3}^{-}$at 3-5 $\mathrm{m}$ depth and the simultaneous increase of the $\mathrm{NO}_{2}^{-}$. The excess of $\mathrm{NO}_{2}^{-}$can be related to synthetic fertilizers, mineralized fertilizer and in particular to degradation of soil organic matter, denitrification processes or contamination by manure and/or sewage. In our case, the increase of $\mathrm{NO}_{2}^{-}$and the simultaneous decrease of $\mathrm{NO}_{3}$ - suggests the occurrence of degradation of organic matter and in particular, denitrification processes, where nitrate is reduced to produce molecular nitrogen $\left(\mathrm{N}_{2}\right)$ through a series of intermediate products, such as $\mathrm{NO}_{2}^{-}$(CLARK \& FRITZ, 1997; MAYER et alii, 2002).

As observed for lake water chemistry, the composition of dissolved gases does not show significant changes along the vertical profile. The most striking features of Lake Bullicante is the relative high concentrations of dissolved $\mathrm{CO}_{2}$ along the whole vertical profile and as suggested by the $\mathrm{N}_{2}-\mathrm{CO}_{2}-\mathrm{O}_{2}$ ternary diagram (Fig. 9), where the concentrations of dissolved gases of the lake water and the adjacent wells (PIzzino, 2015) are reported. The relatively low and high concentration of dissolved $\mathrm{O}_{2}$ and $\mathrm{CO}_{2}$ respectively, along the vertical profile of the lake may be ascribed to processes that take place in the lake itself. Generally speaking, major processes controlling $\mathrm{O}_{2}$ and $\mathrm{CO}_{2}$ in freshwater lakes, are $i$ ) the enhanced biological productivity resulting from high input of nutrients and ii) the high organic matter supply provided by soil erosion

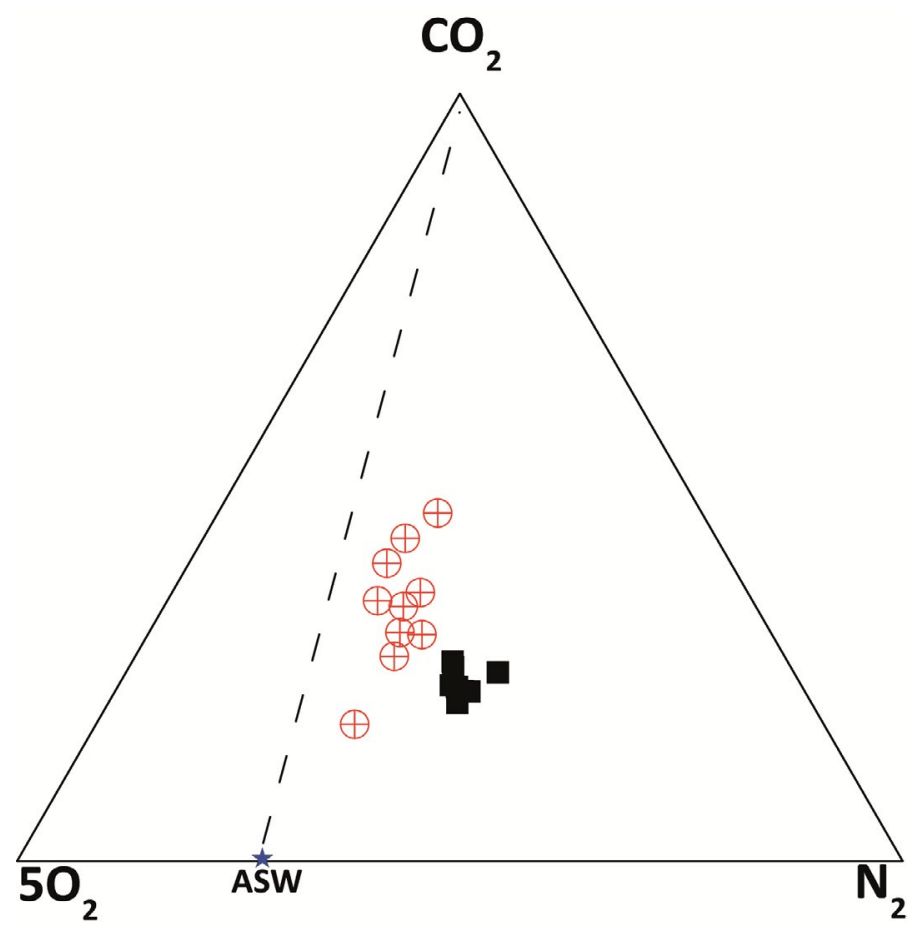

Fig. 9 - $\mathrm{N}_{2}-\mathrm{CO}_{2}-\mathrm{O}_{2}$ ternary diagram for dissolved gases. Molar concentrations are expressed in $\mathrm{mmol} / \mathrm{L}$. ASW = air saturated water at $20^{\circ} \mathrm{C}$. Symbols as in Fig. 6 . 
in the drainage areas (LIKENS, 1972). Nutrient overloading may produce the eutrophication of lakes, a condition that tends to be more frequent in urban environments than in natural systems (SCHUEler \& Simpson, 2001; NASELliFLORES, 2008; LiANG et alii, 2019).

The calculated $\delta^{13} \mathrm{C}$ values lower than $-21 \%$ V-PDB, suggest a biogenic source of $\mathrm{CO}_{2}$ (CERLING et alii, 1991) and support the hypothesis of the high input of nutrients, a related enhanced biological productivity and as a consequence suggest possible eutrophication of the lake. However, considering that i) past degassing phenomena in the study area (CAMPONESCHI \& NolAsco, 1982) have demonstrated the rise of isotopically "heavier" $\mathrm{CO}_{2}$ deriving from crustal-mantle inorganic sources (e.g., Chiodini \& Frondini, 2001; CinTI et alii, 2017) and that ii) the $\mathrm{CO}_{2}$ of the adjacent wells is likely of mixed biogenic and inorganic source (PIzzino, 2015), the hypothesis of an inflow of inorganic $\mathrm{CO}_{2}$ into the lake cannot be completely excluded. This makes further investigations necessary especially during the summer, when the lake is stratified.

DOC concentration confirms the trophic condition generally attributed to eutrophic lakes with residence time of years. Lakes with reduced volumes are reported to have DOC above $10 \mathrm{mg} / \mathrm{L}$ and this is quite uncommon for largest lakes (HANson et alii, 2003; SoBEK et alii, 2007; HANson et alii, 2011). DOC peak of about $40 \mathrm{mg} / \mathrm{L}$ at 0.5 just below the surface $(0.5 \mathrm{~m}$ depth $)$ is most probably due to the accumulation of less degradable organic matter products of photobleaching degradation, that is common in organic rich lakes (BRINKMANN et alii, 2003) with intense microbial activities. This is also confirmed by the increased value of $S_{R}$ at this depth. $S_{R}$ increase due to photodegradation or input autochthonous humid organic matter and decrease due to microbial activity in dark layers (Helms et alii, 2008). SR decreases towards the bottom of the lake due to most probably to the release of aromatic organic matter from bottom sediments. Extremely low $\mathrm{SUVA}_{254}$ values are likely related to photodegradation processes or the contribution of autochthonous organic matter of small dimensions. SUVA $_{254}$ is a good indicator of the humic fraction of the DOC (WEISHAAR et alii, 2003). In rivers, a value of 5-10 is common and an increase is generally observed due to sediment contribution. In our case, this explains the highest SUVA value at water sediment interface (Fig. $5 \mathrm{c}$ ).

Cell abundance values is one or two orders of magnitude higher that those found in surface waters of the central Italian lakes (FAZI et alii, 2016; TASsI et alii, 2018), underlining the eutrophication state of the Lake Bullicante. Values similar to those registered in Lake Bullicante, were found in the deepest layers of meromitic volcanic lakes, highly loaded in nutrients, in eutrophic Tyrrhenian coastal lakes and wastewaters (Pizzetti et alii, 2016; Amalfitano et alii, 2018; TASsI et alii, 2018). The occurrence of phytoplanktonic microorganisms (Cyanobacteria, PicoEukaryotes, Nano-Eukaryotes) was also relatively high, with no consistent changes along the depth, and with values comparable to those found in lake waters at high nutrient levels and blooming conditions (CALLIERI, 2008; TromBETTA et alii, 2019). This could indicate a complete remixing of the water columns during winter, in comparison with the clear thermal stratification in summer, and a high rate of microbial respiration in water that counterbalance primary production, resulting in a low oxygen concentration along the entire water column.

\section{Conclusion}

This study was motivated by the possibility to use the Lake Bullicante as potential open-air laboratory to trace, in a highly urbanized area as Rome, possible degassing phenomena related to the nearby Alban Hills Volcanic District, because violent $\mathrm{CO}_{2}$-degassing from waters were historically here recognized. Our results show that the hydrological circuit feeding the lake is closely related to the shallow volcanic aquifer feeding the nearby water wells. Moreover, the relatively high concentration of biogenic $\mathrm{CO}_{2}$ and the high content of organic matter, highlight that the lake is eutrophic and denitrification processes also occurring. The absence of anomalous concentration in phosphates, ammonium and sulphates, proxies of contamination, strengthen the hypothesis of denitrification and exclude possible sewage input. Isotopic analyses of $\mathrm{N}_{2}$ and $\mathrm{O}_{2}$ of $\mathrm{NO}_{3}^{-}$along the entire water column could provide more detailed information, to definitively exclude the idea of potential contamination. Nevertheless, considering the past inorganic $\mathrm{CO}_{2}$ degassing phenomena occurred in the study area related to crustal-mantle sources, and that, both the lake and adjacent wells present relatively high concentrations of dissolved $\mathrm{CO}_{2}$, an external-lake input of $\mathrm{CO}_{2}$ cannot be completely excluded, and as a consequence, not even the hypothesis of mixing processes between biotic and inorganic $\mathrm{CO}_{2}$. This makes further investigations necessary especially during the summer, when the lake is stratified and even more $\mathrm{CO}_{2}$ could build up near the bottom of the lake. A summer survey could be also useful to better understand the microbial processes in the lake because the high abundance in organic matter, recorded along the winter profile of the lake, could have important implications for the trophic state of the lake, bringing to potential toxic blooms. The results of further campaigns would contribute to deeply understand the eutrophication evolution of the lake, its health status and plan eventual proper remediation strategies such as, in-lake actions and lake basin management, providing important tools to the local administration and stakeholders to improve, protect and preserve this important aquatic system.

\section{ACKNOWLEDGEMENTS}

Many thanks are due to the INGV Laboratory of Palermo for the technical support in the dissolved gases, isotopic and trace elements analysis. We thank Alessandra Sciarra for dissolved gas analysis of waters from wells. We wish to express our gratitude also to Maila Severini for the assistance in microbiological analysis, to Emanuela Bagnato and Andrea Gasparini for their help in field measurements, to Maurizio Pastano for his support during the field work and to Antonio Caracausi for his useful suggestions. We would like to thank William C. Evans and the anonymous Reviewer for their time spent on reviewing our manuscript and their comments helping us improving the article. The Issue editors are also thanked for receiving and handling our manuscript. We dedicate this study to Prof. Mariano Valenza for being the Master to us and many of our peers. This work was partially funded by, Davines SpA in the framework of the call "Ricerca il Futuro 2017" dedicated to the women researchers, and by the INGV project "FISR Italia Centrale 2018".

\section{REFERENCES}

Amalfitano S., Levantesi C., Garrelly L., Giacosa D., Bersani F. \& Rossetti S. (2018) - Water quality and total microbial load: a doublethreshold identification procedure intended for space applications. Front. Microbiol., 9, 2903. 
Battisti C., Dodaro G. \& Fanelli G. (2017) - Paradoxical environmental conservation: Failure of an unplanned urban development as a driver of passive ecological restoration. Environmental Development, 24, 179186.

Barbieri M., Masi U. \& Tolomeo L. (1979) - Origin and distribution of strontium in the travertines of Latium (Central Italy). Chem. Geol., 24, 181-188.

Boari E., Avanzinelli R., Melluso L., Giordano G., Mattei M., De Benedetti Arnaldo A., Morra V. \& Conticelli S. (2009) - Isotope geochemistry $(\mathrm{Sr}-\mathrm{Nd}-\mathrm{Pb})$ and petrogenesis of leucite-bearing volcanic rocks from "Colli Albani” volcano, Roman Magmatic Province, Central Italy: inferences on volcano evolution and magma genesis. Bull. Volcanol. 71, 977-1005.

Brinkmann T., Sartorius D. \& Frimmel F.H. (2003) - Photobleaching of humic rich dissolved organic matter. Aquat. Sci., 65, 415-424.

Cabassi J., Capecchiacci F., Magi F., Vaselli O., Tassi F., Montalvo F., Esquivel I., Grassa F. \& CAPrai A. - Water and dissolved gas geochemistry at Coatepeque, Ilopango and Chanmico volcanic lakes (El Salvador, Central America). J. Volcanol. Geother. Res., 378, 1-15.

CALlieri C. (2008) - Picophytoplankton in freshwater ecosystems: the importance of small-sized phototrophs. Freshwater Reviews, 1, 1-28.

Camponeschi B. \& Nolasco F. (1982) - Roma e i Colli Albani. In: Le risorse naturali della regione Lazio, Vol. 7.

CAPASso G. \& Inguaggiato S. (1998) - A simple method for the determination of dissolved gases in natural waters. An application to thermal waters from Vulcano Island. Appl. Geochem, 13, 631-642.

Capelli G., Mazza R. \& Taviani S. (2008) - Acque sotterranee nella città di Roma. Mem. Descr. Carta Geol. D’It. LXXX, pp. 221-245.

Carapezza M. L., Barberi F., Ranaldi M., Tarchini L., \& Pagliuca N.M. (2019) - "Faulting and gas discharge in the Rome area (Central Italy) and associated hazards". Tectonics, 38, 941-959.

CARAPEZZA M.L. \& TARChINI L. (2007) - Accidental gas emission from shallow pressurized aquifers at Alban Hills volcano (Rome, Italy): geochemical evidence of magmatic degassing? J. Volcanol. Geotherm. Res., 165, 5-16.

Cerling T.E., Solomon D.K., Quade J. \& Bowman J.R. (2019) - On the isotopic composition of carbon in soil carbon dioxide. Geoch. Cosmoch. Acta, 55, 3403-3405.

Chiodini G. \& Frondini F. (2001) - Carbon dioxide degassing from the Albani Hills volcanic region, Central Italy. Chem. Geol., 177, 67-83.

Cinti D., Tassi F., Procesi M., Vaselli O. \& Voltattorni N. (2017) Geochemistry of hydrothermal fluids from the eastern sector of the Sabatini Volcanic District (central Italy). App. Geoch., 84, 187-2011.

CLARK I. \& FRITZ P. (1997) - Environmental isotopes in hydrogeology. Lewis Publishers, Boca Raton, New York, 328pp.

CRAIG H. (1961) - Isotopic variations in meteoric waters. Science, 133, 1702-1703.

De Rita D., Cremisi C., Cinnirella A. \& Spaziani F. (2011) - Fluorine in the rocks and sediments of volcanic areas in central Italy: Total content, enrichment and leaching processes and a hypothesis on the vulnerability of the related aquifers. Environmental Monitoring and Assessment, 184, 5781-5796.

Deuser W.G. \& Degens E.T. (1967) - Carbon isotope fractionation in the system $\mathrm{CO}_{2}$ (gas)- $\mathrm{CO}_{2}$ (aqueous)- $\mathrm{HCO}_{3}$ (aqueous). Nature, 215, 1033-1035.

Fazi S., Crognale S., Casentini B., Amalfitano S., Lotti F. \& Rossetti S. (2016) - The arsenite oxidation potential of native microbial communities from arsenic-rich freshwaters. Microb. Ecol., 72, 2535 .

Freda C., Gaeta M., Misiti V., Mollo S., Dolfi D. \& Scarlato P. (2008) - Magma-carbonate interaction: an experimental study on ultrapotassic rocks from Alban hills (Central Italy). Lithos, 3-4, 397-415.

Funiciello R., Giordano G. \& De Rita D. (2003) - The Albano Maar lake (Colli Albani Volcano, Italy): recent volcanic activity and evidence of pre-Roman Age catastrophic lahar events. J. Volcanol. Geotherm. Res., 123, 43-61.

Gambardella B., Marini L. \& Baneschi I. (2005) - Dissolved potassium in the shallow groundwaters circulating in the volcanic rocks of central-southern Italy. App. Geochem., 20, 875-897.

GonzÁlez E. J. \& Roldán G. (2019) - Eutrophication and Phytoplankton: Some Generalities from Lakes and Reservoirs of the Americas. Microalgae - From Physiology to Application. Ed. Milada Vítová. IntechOpen. https://doi.org/10.5772/intechopen.89010
Gasol J.M. \& Morán X.A.G. (2015) - Flow cytometric determination of microbial abundances and its use to obtain indices of community structure and relative activity. In: McGenity, T., Timmis, K., Nogales B. (Eds.) Hydrocarbon and Lipid Microbiology Protocols. Springer Protocols Handbooks. Springer, Berlin, Heidelberg.

GAT J.R. \& CARMI I. (1970) - Evolution of the isotopic composition of atmospheric waters in the Mediterranean Sea area. J. Geophys. Res., 75, 3039-3048.

Hanson P.C., Bade D.L., Carpenter S.R. \& Kratz T.K. (2003) Lake metabolism: Relationships with dissolved organic carbon and phosphorus. Limnol Oceanogr., 48, 1112-1119.

Hanson P.C., Hamilton D.P., Stanley E.H., Preston N., Langman O.C. \& Kara E.L. (2011) - Fate of Allochthonous Dissolved Organic Carbon in Lakes: A Quantitative Approach. PLoS ONE, 6, e21884.

Helms J.R., Stubbins A., Ritchie J.D., Minor E.C., Kieber D.J. \& Mopper K. (2008) - Absorption spectral slopes and slope ratios as indicators of molecular weight, source, and photobleaching of chromophoric dissolved organic matter. Limn. Oceanogr., 53, 955-969.

La Vigna F., Mazza R., Amanti M., Di Salvo C., Petitta M., Pizzino L., Pietrosante A., Martarelli L., Bonfa' I., Capelli G., Cinti D., Ciotoli F., Ciotoli G., Conte G., Del Bon A., Dimasi M., Falcetti S., Gafà R.M., Lachini A., Mancini M., Martelli S., Mastrorillo L., Monti G.M., Procesi M., Roma M., Sciarra A., Silvi A., Stigliano F. \& Succhiarelli C. (2016) - Groundwater of Rome. J. Maps, 12, 88-93.

Liang J., Huang C., Stevenson M.A., Qiao Q., Zeng L. \& Chen X. (2019) - Changes in summer diatom composition and water quality in urban lakes within a metropolitan area in central China. Int. Rew. Hydrobiol., https://doi.org/10.1002/iroh.201801953

LiKens G.E. (1972) - Mirror Lake - its past, present and future? Appalachia, 39, 23-41.

Lugli F., Cipriani A., Peretto C., Mazzucchelli M. \& Brunelli D. (2017) - In situ high spatial resolution ${ }^{87} \mathrm{Sr} /{ }^{86} \mathrm{Sr}$ ratio determination of two Middle Pleistocene (ca $580 \mathrm{ka}$ ) Stephanorhinus hundsheimensis teeth by LA-MCICP-MS. Int. J. Mass Spectrom., 412, 38-48.

Marra F., Freda C., Scarlato P., Taddeucci J., Karner D.B., Renne P.R., Gaeta M., Palladino D.M., Trigila R. \& Cavarretta G. (2003) Post-caldera activity in the Alban Hills volcanic district (Italy): $40 \mathrm{Ar} / 39 \mathrm{Ar}$ geochronology and insights into magma evolution. Bull. Volcanol., 65, 227-247.

Marra F., Karner D.B., Freda C., Gaeta M. \& Renne P.R. (2009) Large mafic eruptions at Alban Hills Volcanic District (Centralltaly): Chronostratigraphy, petrography and eruptive behavior. J. Volcanol. Geother.Res., 179, 217-232.

Mayer B., Boyer E.W., Godale C., Jaworski N.A., Breemen N.V. Howarth R.W., Seitzinger S., Billen G., Lajtha K., Nadelhoffer K., Dam D.W., Hetling L.J., Nosal M. \& Paustian K. (2002) - Sources of nitrate in rivers draining sixteen watersheds in the northeastern U.S. Isotopic constrain. Biogeochem., 57/58, 171-197.

Minissale A., Donato A., Procesi M., Pizzino L. \& Giammanco S. (2019) - Systematic review of geochemical data from thermal springs, gas vents and fumaroles of Southern Italy for geothermal favourability mapping. Earth-Sci Rev, 188, 514-535.

Mook W.G., Bommerson J.C. \& Staverman W.H. (1974) - Carbon isotope fractionation between dissolved carbonate and gaseous carbon dioxide. Earth Planet. Sci. Lett., 22, 169-176.

Naselli-Flores L. (2008) - Urban Lakes: Ecosystems at Risk, Worthy of the Best Care. Proceedings of Taal: The 12th World Lake Conference: 1333-1337.

Parkhurst D.L. \& Appelo C.A.J. (2013) - Description of input and examples for PHREEQC version 3-A computer program for speciation, batchreaction, one-dimensional transport, and inverse geochemical calculations. U.S.G.S. Tech. Methods, book 6, chap. A43 497 available at: http:// pubs.usgs.gov/tm/06/a43.

Pearce C.R., Parkinson I.J., Gaillardet J., Chetelat B. \& Burton K.W. (2015) - Characterising the stable $\left(\delta^{88}{ }^{86} \mathrm{Sr}\right)$ and radiogenic ${ }^{87} \mathrm{Sr} /{ }^{86} \mathrm{Sr}$ ) isotopic composition of strontium in rainwater. Chem. Geol., 409, 54-60.

Pizzetti I., Schulz F., Tyml T., Fuchs B.M., Amann R., Horn M. \& FAZI S. (2016) -Chlamydial seasonal dynamics and isolation of 'Candidatus Neptunochlamydia vexilliferae' from a Tyrrhenian coastal lake. Environ. Microbiol., 18, 2405-2417.

Pizzino L., Galli G., Mancini C., Quattrocchi F. \& Scarlato P. (2002) Natural gas hazard $\left(\mathrm{CO}_{2},{ }^{222} \mathrm{Rn}\right)$ within a quiescent volcanic region and its relations with tectonics: the case of the Ciampino-Marino area, Alban Hills Volcano, Italy. Nat. Hazards, 27, 257-287. 
Pizzino L. (2015) - "Fluid geochemistry and Natural Gas Hazard in the urban area of Rome”. Tesi di dottorato, in italian, Università degli Studi Roma 3, 152 pp.

Salata G.G., Roelke L.A. \& Cifuentes L.A. (2000) - A rapid and precise method for measuring stable isotope ratios of dissolved inorganic carbon. Mar. Chem., 69, 153-161.

Schueler T. \& Simpson J. (2001) - Why urban lakes are different. Water Protection Techniques, 3, 747-750.

Sobek S., Tranvik L.J., Prairie Y.T., Kortelainen P. \& Cole J. (2007) Patterns and regulation of dissolved organic carbon: An analysis of 7,500 widely distributed lakes. Limnol. Oceanogr., 52, 1208-1219.

Trombetta T., Vidussi F., Mas S., Parin D., Simier M. \& Mostajir B. (2019) - Water temperature drives phytoplankton blooms in coastal waters. PloS ONE, 14, e0214933.

Tassi F., Fazi S., Rossetti S., Pratesi P., Ceccotti M., Cabassi J., Capecchiacci F., Venturi S. \& VAselli O. (2018) - The biogeochemical vertical structure renders a meromictic volcanic lake a trap for geogenic $\mathrm{CO}_{2}$ (Lake Averno, Italy). PLoS ONE, 13, e0193914.

TASsI F. \& RouwET D. (2014) - An overview of the structure, hazards, and methods of investigation of Nyos-type lakes from the geochemical perspective. J Limnol., 73, 55-70.
Twardowski M.S., Boss E., Sullivan J.M. \& Donaghay P.L. (2004) - Modeling the spectral shape of absorption by chromophoric dissolved organic matter. Mar. Chem., 89, 69-88.

VeIzer J. (1989) - Strontium isotopes in seawater through time. Ann. Rev. Earth Planet. Sci., 17, 141-167.

WAgner T. \& ERICKSON L.E. (2017 - Sustainable Management of Eutrophic Lakes and Reservoir. J. Environ. Prot. Ecol., 8, 436-463.

Washington H.S. (1906) The Roman comagmatic region. Carnegie Inst. Washington Publ., 57

Weishatr J.L., Aiken G.R., Bergamaschi B.A., Fram M.S., Fuji R. \& Mopper K. (2003) - Evaluation of specific ultraviolet absorbance as an indicator of the chemical composition and reactivity of dissolved organic carbon. Environ. Sci. Technol., 37, 4702-4708.

Whitfield M. (1978) - Activity coefficients in natural waters. In Pytkowicz, R.M. (Ed.), Activity Coefficients in Electrolyte Solutions. CRC Press, Boca Raton, FL, pp. 153-300.

Zhang J, Quay Pd \& Wilbur Do. (1995) - Carbon isotope fractionation during gas-water exchange and dissolution of $\mathrm{CO}_{2}$. Geochim. Cosmochim. Acta, 59, 107-114. 